\title{
Molecular Mechanisms of Go Signaling
}

\author{
Meisheng Jiang Neil S. Bajpayee \\ Department of Molecular and Medical Pharmacology, David Geffen School of Medicine, University of California, \\ Los Angeles, Calif., USA
}

\section{Key Words}

G protein $\cdot$ Go $\cdot$ G-protein-coupled receptors $\cdot$ Signal transduction · Effectors • Central nervous system •

Alzheimer's disease

\begin{abstract}
$\mathrm{Go}$ is the most abundant $\mathrm{G}$ protein in the central nervous system, where it comprises about $1 \%$ of membrane protein in mammalian brains. It functions to couple cell surface receptors to intercellular effectors, which is a critical process for cells to receive, interpret and respond to extracellular signals. Go protein belongs to the pertussis toxin-sensitive $\mathrm{Gi} /$ Go subfamily of $G$ proteins. A number of G-protein-coupled receptors transmit stimuli to intercellular effectors through Go. Go regulates several cellular effectors, including ion channels, enzymes, and even small GTPases to modulate cellular function. This review summarizes some of the advances in Go research and proposes areas to be further addressed in exploring the functional role of Go.
\end{abstract}

Copyright $\odot 2009$ S. Karger AG, Base

\section{Introduction}

In the late 1950s and early 1960s, Earl Sutherland discovered that cyclic AMP (cAMP) was a second messenger in hormone signaling while studying how epinephrine, a stress hormone, mobilized blood glucose by degrading glycogen to glucose in the liver. Epinephrine increased the accumulation of cAMP in cells by stimulating aden- ylyl cyclase. These findings opened the door for research on the mechanisms that control hormone action. In the early 1970s, Martin Rodbell and Lutz Birnbaumer [1] demonstrated that guanosine nucleotide triphosphate (GTP) is required for stimulation of adenylyl cyclase activity in adipocyte membrane preparations. Further investigation revealed that GTP affects hormone receptorbinding properties. The discovery of a GTP requirement for transducing extracellular signals into cells provided the basis for the existence of GTP-binding G proteins (formally referred to as $\mathrm{N}$ proteins for nucleotide-binding protein). In the late 1970s, Alfred Gilman and associates $[2,3]$ isolated and identified the first GTP-binding protein, Gs (stimulatory regulator of adenylyl cyclase G protein) and provided direct evidence that the GTP-binding protein acts as a signaling molecule in hormone signaling. Meanwhile, another GTP-binding protein, transducin (Gt), was identified as a signal transducer in bovine retina [4]. Transducins, abundant in the outer retinal segments, couple rhodopsin to cyclic GMP-dependent phosphodiesterase and transmit incoming photons into chemical signals.

The use of two bacterial toxins has greatly facilitated the identification and characterization of $G$ proteins. Cholera toxin, from Vibrio cholerae bacteria, mediates ADP ribosylation of the Gs protein and was used in the early characterization and purification of Gs [5-7]. Bordetella pertussis toxin (PTX), discovered as the islet-activating protein, mediates the ADP ribosylation of Gi proteins (which inhibit adenylyl cyclase activity) $[8,9]$. Treatment of cells or membranes with PTX results in the loss

\section{KARGER}

Fax +4161306 1234 E-Mail karger@karger.ch www.karger.com
(C) 2009 S. Karger AG, Basel

$1424-862 X / 09 / 0171-0023 \$ 26.00 / 0$

Accessible online at:

www.karger.com/nsg
Dr. Meisheng Jiang

Department of Molecular and Medical Pharmacology

David Geffen School of Medicine, University of California Los Angeles

710 Westwood Plaza, Reed 3127, Los Angeles, CA 90095 (USA)

Tel. +1 310794 7802, Fax +1 310794 7380, E-Mail jm@ucla.edu 
of adenylyl cyclase inhibition. Adenylyl cyclase inhibitory $G$ proteins, Gi proteins, were first purified and identified by the Gilman and Birnbaumer groups independently $[10,11]$. Go protein, the fourth member of the G protein family, was discovered during purification of Gi from the bovine brain. Go was named as the 'other' GTP-binding protein after Gs, Gi, and transducin [12-14]. The brain contains abundant Go protein as demonstrated by PTXmediated ADP-ribosylation labeling. The first partial cDNA clone of Go was isolated by screening a rat glioma cDNA library for Gi cDNA using oligonucleotide probes derived from the Gi peptide sequence [15]. Since these initial findings, Go has been identified as the most abundant brain $G$ protein and has received considerable attention to determine its physiological role in the body.

\section{Biophysical Properties, Distribution, and Expression}

\section{Abundant Expression in Brain Tissue}

Go protein was discovered serendipitously during attempts to purify Gi protein from the brain. GTP $\gamma S$-binding and ADP-ribosylation assays were well established for purifying and characterizing the Gs and Gi proteins. A high level of GTP $\gamma S$-binding activity was observed in brain preparations from two species and was severalfold higher than in other tissues. PTX-mediated ADP ribosylation and electrophoresis of brain samples revealed the abundant presence of a $39-\mathrm{kDa}$ protein in addition to the 41-kDa Gi $\alpha$ subunit. Go contains three subunits with molecular weights of $39-\mathrm{kDa}$ ( $\alpha$ subunit), $36-\mathrm{kDa}$ ( $\beta$ subunit), and $10-\mathrm{kDa}$ ( $\gamma$ subunit). Its $\beta \gamma$ complex appears indistinguishable from that of Gi's. Go is 5- to 10 -fold more abundant than other Gi proteins in the brain and accounts for an estimated $0.5-1 \%$ of total membrane protein. Like Gi, Go is a substrate of PTX ADP ribosylation. PTX-mediated ADP ribosylation requires the integrity of the heterotrimeric complex as the $\beta \gamma$ subunit is needed for ADP ribosylation of the $\alpha$ subunit.

\section{Affinity to Guanine Nucleotides and GTPase Activity}

Study of purified Gi/o proteins from bovine brain revealed that the GDP/Go protein ratio is around 0.9 while the GDP/Gi protein ratio is 0.6 [16]. The GDP/G protein ratio may reflect the stability of the individual $G$ proteins and it suggests that the Go-GDP complex is relatively more stable than the Gi-GDP complex. GDP-GTP exchange is critical for the activation of $G$ protein signaling, while the dissociation of GDP from the $\alpha$ subunit is the rate-limiting step [3]. Binding studies have revealed that the kinetics of GTP $\gamma \mathrm{S}$ association with either the heterotrimeric Go or Go $\alpha$ subunit is rapid. The rate of dissociation of GDP from Go as well as the association of GTP $\gamma$ S with Go are about 3 times faster than those with Gi protein. In addition, the intrinsic GTPase activity of Go is about 3-7 times higher than that of Gi. The GTPase of the $\alpha$ subunit hydrolyzes GTP to GDP, which converts $G$ proteins from an active to an inactive state, and subsequently controls signal duration. Taken together, Go is a highly effective molecular signaling transducer (i.e. a fast on-off switch). How this physical property correlates to functional signaling has not been elucidated.

Many protein factors are involved in signal transduction through $G$ proteins to regulate the strength, duration, efficiency, and specificity of signaling. These factors can be classified into two major groups based on their effect on $G$ protein activity: either influencing the rate of guanine nucleotide exchange or the rate of hydrolysis of bound GTP. Guanine nucleotide exchange factors (GEF) modulate the guanine nucleotide exchange rate, while GTPase-activating proteins (GAP), and regulators of Gprotein signaling (RGS) influence the rate of GTP hydrolysis by the $\mathrm{G} \alpha$ subunit. Together they facilitate the 'onoff' switch of the $G$ protein signal.

G-protein-coupled receptors (GPCRs) are widely recognized as GEFs for heterotrimeric G proteins. Many receptors have been identified to couple to Go protein. In addition to coupled receptors, several non-receptor proteins have been shown to influence nucleotide binding by the Go $\alpha$ subunit, including the growth cone-associated protein with molecular weight of $43 \mathrm{kDa}$ (GAP-43), amyloid precursor protein (APP), and Presenilin I. GAP-43 was originally identified as an axonally transported protein. It is expressed at high levels in the developing nervous system of vertebrates and is localized in the inner surface of growth cone membranes. GAP- 43 binds to and interacts with Goo, where it increases the rate of GDP dissociation and GTP association as was demonstrated with purified brain heterotrimeric $\mathrm{G}$ proteins as well as with purified Go $\alpha$ subunits $[17,18]$. PTX does not alter the activation of Go protein by GAP-43. Activator of Gprotein signaling (AGS) is another GEF involved in regulating Go-mediated signaling. AGS was identified using a modified yeast pheromone response pathway which is mediated by G protein [19]. In addition, AGS binds to the Go $\alpha$ subunit in protein-binding assays. In vitro, AGS greatly enhances GTP $\gamma \mathrm{S}$ binding to purified Go/Gi proteins [20]. The paralog of human AGS1 in mice, Dexras1, was identified by rapid mRNA upregulation in AtT-20 corticotrophin cells after glucocorticoid treatment [21]. 
Overexpression of a constitutively active form of Dexras1/ AGS1 greatly inhibits peptide hormone release from corticotrophin cells. The removal of the C-terminal prenylation site of Dexras1/AGS1 diminishes these inhibitory effects [22]. This implicates AGS as a GEF for Gi/o proteins, adding another mechanism that can modulate Go signaling.

In addition to the enhancing modulators of guanine nucleotide exchange, protein factors that decrease the guanine nucleotide exchange rate have also been identified. These are known as the GRP (G protein regulatory) or GoLoco motifs and can bind to Go $\alpha$ and stabilize it in the GDP-bound conformation while simultaneously competing with $\mathrm{G} \beta \gamma$ for $\mathrm{G} \alpha$ binding $[23,24]$. RGS proteins, on the other hand, are responsible for the rapid deactivation of receptor-stimulated $G$ protein signals. RGS proteins negatively regulate $G$ protein signaling by accelerating $\alpha$ subunit GTPase activity, physically blocking $G$ protein effector binding and altering the level of free $\beta \gamma$ subunits available to their downstream effectors [25]. The RGS4 protein and the $\mathrm{G} \alpha$-interacting protein (GAIP) can selectively accelerate the deactivation of Gi and Go protein, respectively [26]. When the N-terminus of GAIP was deleted, the selectivity towards Go $\alpha$ was lost [27]. Recombinant RGS1, RGS16, and GAIP can stimulate the GTPase activity of Gol $\alpha$ following its activation by an agonist of the $\alpha_{2} \mathrm{~A}$-adrenoreceptor [28]. These studies demonstrate that the duration and specificity of receptorstimulated Go protein signaling is also regulated by RGS proteins.

\section{Conserved across Many Species}

After the partial cDNA sequence for rat Go was first reported [15], cDNAs encoding Go $\alpha$ have been cloned and identified in many species, including human [29], rat [30], mouse [31], hamster [32], bovine [33], zebra fish [34], Xenopus [35], Drosophila [36-38], nematode [39] and silkmoth [40]. Go $\alpha$ is highly conserved across species, including fruit flies and Caenorhabditis elegans which share more than $80 \%$ identity to human Go (fig. 1). This high degree of similarity in protein sequence suggests that Go-mediated signaling pathways are critical for organisms in receiving, integrating, and executing the transduction of extracellular stimuli across species.

\section{Two Isoforms, Generated via Alternative Splicing}

The abundance of Go protein in the brain made it easier to purify, allowing biochemical characterization of the $\alpha$ subunit in functional reconstitution experiments with receptors. However, during the course of purifica- tion, heterogeneity of the Go $\alpha$ subunit samples was observed. A novel and less abundant form of Go $\alpha$ was observed and purified with the 39-kDa Go $\alpha$ [41]. In situ peptide mapping revealed sequence differences between each isoform [42]. This heterogeneity of the Goo subunit was also observed in membrane preparations from canine cardiac sarcolemma [43]. cDNA clones encoding both Go $\alpha$ forms were subsequently identified from both a HIT (hamster insulin-secreting tumor) cell cDNA library [32] and a mouse brain cDNA library [44]. The deduced amino acid sequences of the cDNAs revealed that the first two-thirds of the N-terminal residues ( 248 of 354 amino acids) of $\mathrm{G} \alpha \mathrm{ol}(\mathrm{GoA} \alpha)$ and $\mathrm{G} \alpha \mathrm{o} 2(\mathrm{GoB} \alpha)$ are identical. Of the remaining C-terminal residues (116 out of 354), the two forms differ by only 25 or 26 amino acids (25 in mouse, 26 in hamster and 20 in human). At the level of nucleotide sequence, G $\alpha$ ol $(\mathrm{GoA} \alpha)$ and $\mathrm{G} \alpha \mathrm{o} 2$ $(\mathrm{GoB} \alpha)$ are identical up to codon 242 and differ thereafter, including the $3^{\prime}$ untranslated region. The chromosomal gene for human Go $\alpha$ was identified later and analysis of genomic clones revealed that the human Go $\alpha$ gene spans more than $100 \mathrm{~kb}$ on chromosome $16 \mathrm{q} 13$ and contains 11 exons [45]. Gool and $\mathrm{G} \alpha \mathrm{O} 2$ are products of alternative splicing using different sets of exons for the carboxyl terminal and 3' untranslated region. The two isoforms share the first 6 exons that encode the 241 $\mathrm{N}$-terminal amino acids, and each isoform has unique exons 7,8 , and 9 .

\section{Member of the Gi/o Subfamily}

Since the discovery of the first four $G$ proteins (Gs, Gi, Gt and Go), numerous genes encoding additional $G$ proteins have been cloned and identified based on nucleic acid sequence homology with the previously characterized $G$ proteins. 17 mammalian $G$ proteins have been identified in humans, and they can be classified into four subfamilies - Gs, Gi/o, Gq/11, and G12/13 - according to their sequence similarity and the functional relevance of their coupled effectors. The Gi/o subfamily contains two Go members, three Gi, Gz, two transducins (rod and cone), and gustducin. All members in the subfamily, except $\mathrm{Gz}$, are substrates of PTX, which mediates ADP ribosylation at the carboxyl terminal cysteine residue $(-4$ position). As shown in figure 2, all members in the Gi/o family are highly homologous with more than $60 \%$ identity and greater than $70 \%$ similarity, especially among the non-sensory, PTX-sensitive members (Gi and Go). The three Gi $\alpha$ and two Go $\alpha$ subunits display extensive homology in their primary sequence and are functionally similar in vitro, though they differ both in cellular and 


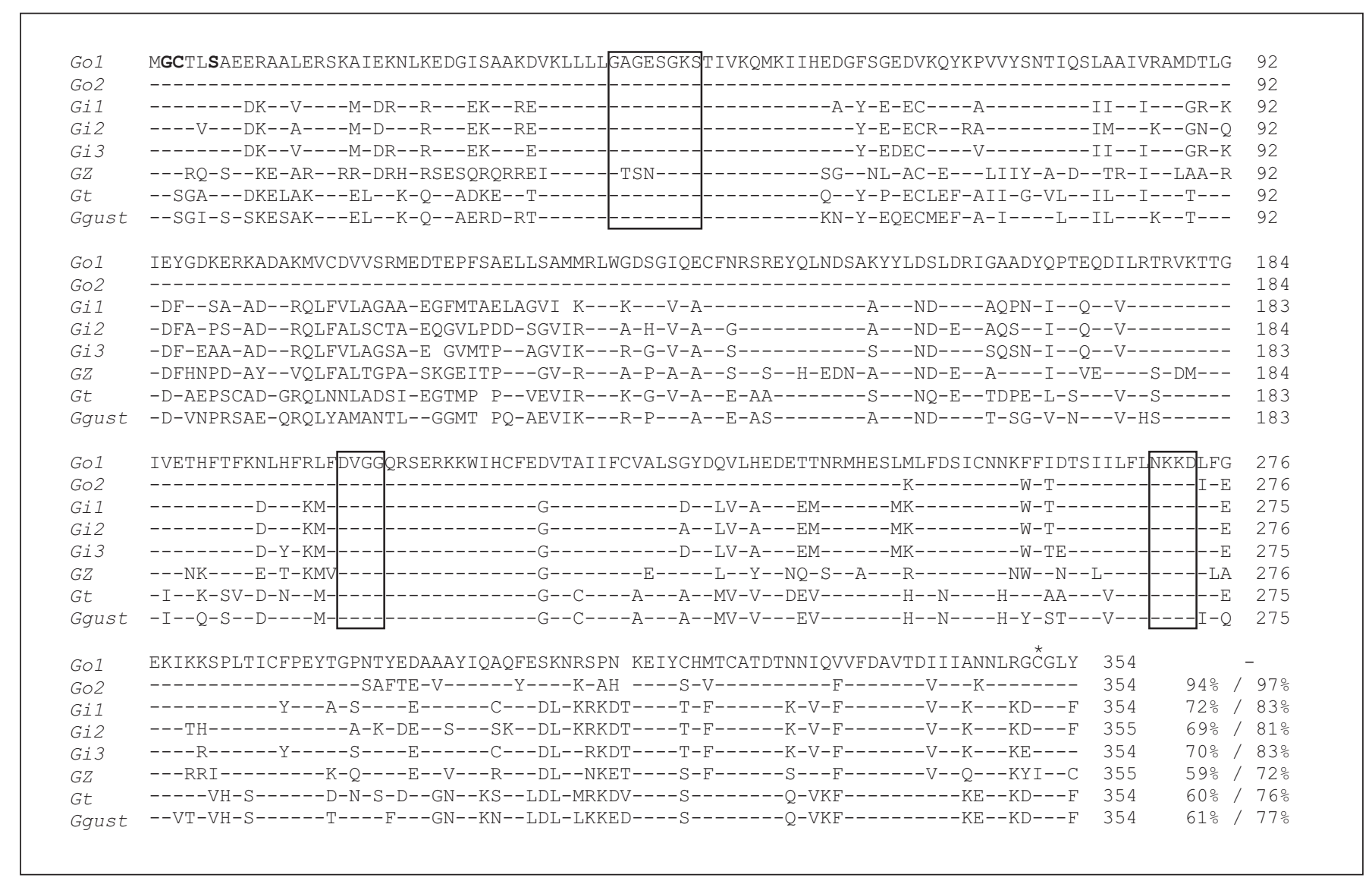

Fig. 1. Protein sequence alignment of the human Gi/o family. $\mathrm{Gly}^{2} / \mathrm{Ser}^{6}$ motif for myristoylation and Cys ${ }^{3}$ for palmitoylation (bold), GTP-binding motif (GAGESGKS), $\mathrm{Mg}^{2+}$-binding domain (DVGG), guanine ring-binding motif (NKKD), cysteine $\left(^{*}\right)$ (at -4 from carboxyl terminal) for PTX ADP ribosylation on Gi/o proteins. Ggust is gustducin $\alpha$ subunit (gnat3). $\mathrm{G}_{\mathrm{t}}$ sequence from cone transducin. Percentage of identity/homology. Spaces for alignment.

subcellular distribution. The high similarity in the protein sequence raised the question whether the individual proteins function distinctively to transmit information between different receptors and effectors or whether they are simply isoforms of one another. The similarity in the primary sequence among Gi/o subunits suggests that they may be functionally coupled to the same (or similar) receptors or may signal to the same effectors. However, the divergence in primary sequence and their unique patterns of tissue distribution strongly suggest that each member may contribute distinctive biological functions in the body. Each gene encoding an $\alpha$ subunit in the Gi/o family has been knocked out in mice [46], and studies of these animals reveal that each knockout has unique deficiencies or abnormalities. These knockout mouse studies support the notion that each member mediates distinctive biological functions in the body.

\section{Lipid Modification}

$\mathrm{G}$ proteins, unlike their coupled receptors, are not transmembrane polypeptides. Therefore, mechanisms that bring $G$ proteins close to receptors at the plasma membrane are critical for $G$ protein signaling. Lipid modification and association with $\beta \gamma$ subunits are the generally accepted mechanisms for anchoring the $\alpha$ subunit to the plasma membrane. Lipid modification has been observed in both the $\alpha$ and $\gamma$ subunits of G proteins with $\mathrm{N}$-myristoylation and/or palmitoylation on the $\alpha$ subunits and prenylation on $\gamma$ subunits. Go protein purified from brain tissue is myristoylated [47]. The glycine at the $\mathrm{N}$-terminus (G2) of G protein is the residue for myristoylation. Substitution of this glycine with an alanine residue (G2A) eliminated incorporation of myristate and resulted in cytosolic retention and no plasma membrane localization of the $\mathrm{G}$ protein $[48,49]$. Furthermore, the 


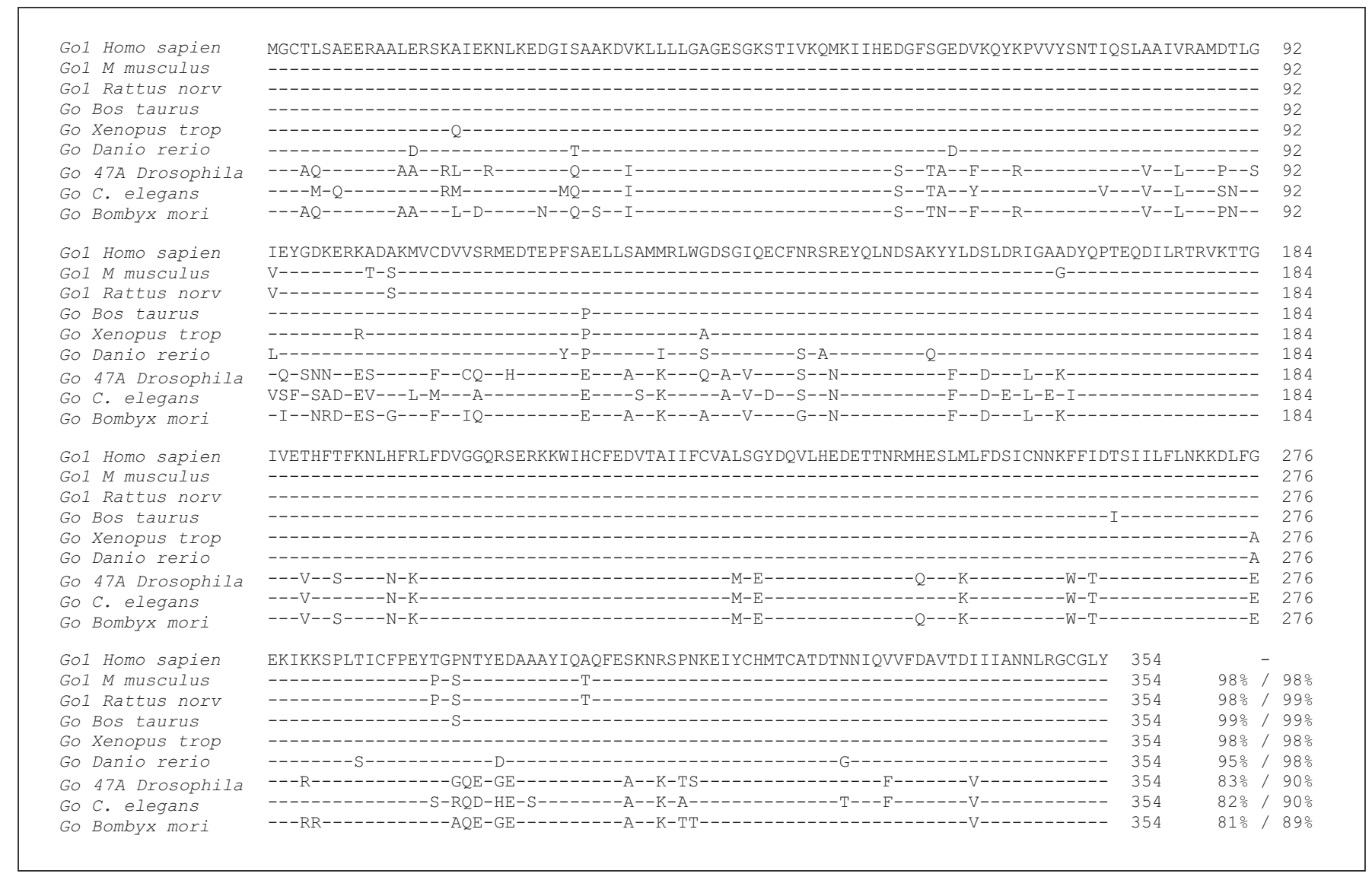

Fig. 2. Protein sequence alignment of Go protein across species. Percentage of identity/homology.

constitutively active form of Gi2 $\alpha$ is oncogenic with transforming activity that is sensitive to lipid modification. The non-myristoylated G2A mutation of this active form is incapable of transforming Rat la fibroblasts [50]. This emphasizes that lipid modification of $\mathrm{G} \alpha$ is important for anchoring $G$ protein to the plasma membrane as well as maintaining its signaling capabilities.

In addition to myristoylation, Go and Gi $\alpha$ subunits are also palmitoylated [51], although myristoylation is a prerequisite to palmitoylation [52]. Palmitoylation of Go $\alpha$ is dynamic and highly regulated. The addition of the agonist adrenaline dramatically reduced palmitoylation of Goo 1 in a fusion protein with the $\alpha_{2} \mathrm{~A}$-adrenoceptor. The reduction in palmitoylation is concentration-dependent and correlates with the occupancy of the ligandbinding site [53]. This suggests that palmitoylation is directly associated with agonist stimulation and may be involved in regulating signals. In this manner, dynamic palmitoylation could provide both temporal and spatial regulation of $G$ protein signaling. Questions regarding how palmitoylation is regulated, whether de-palmitoylation is critical for permitting Go $\alpha$-specific protein interactions and subcellular localization, and how it correlates with Go-mediated signaling need to be addressed.

The G $\beta \gamma$ subunits not only act as a signaling moiety, but also play an important role in controlling $\alpha$ subunit signaling. The binding of $\beta \gamma$ has two functions in Go $\alpha$ signaling: it constitutes an anchorage point on the plasma membrane and assists in coupling the $G$ protein to the proper receptors. Interestingly, the docking site of the $\mathrm{G} \beta \gamma$ subunit is also in the $\mathrm{N}$-terminus of the $\mathrm{G} \alpha$ subunit, adjacent to the myristoylation and palmitoylation sites [54]. Palmitoylation, association with $G \beta \gamma$, and retention of Go $\alpha$ on the plasma membrane act synergistically to maintain proper $G$ protein localization for signaling [55]. 


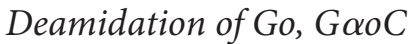

An additional isoform of Go $\alpha$ in bovine brain, $\mathrm{G} \alpha \mathrm{oC}$ (or Go3), was observed during purification and characterization of $\mathrm{Gi} / \mathrm{Go}$ proteins [56]. In the mammalian genome, only one gene encodes Go $\alpha$, and alternative splicing generates two mRNA transcripts, G $\alpha 01$ and $\mathrm{G} \alpha \mathrm{o} 2$. Mass spectrometry sequencing revealed that $\mathrm{G} \alpha \mathrm{oC}$ is identical to $\mathrm{G} \alpha \mathrm{ol}$, except for a single difference at the carboxyl terminus [57]. G $\alpha$ oC differs from $\mathrm{G} \alpha \mathrm{ol}$ by substitution of an Asn347 residue with Asp near the C-terminus in a region involved in receptor activation $[58,59]$. The substitution is a result of a posttranslational modification, deamidation of Asn to Asp. This modification may change the signaling properties since the region is critical for receptor discrimination and binding as well as guanine nucleotide binding. $\mathrm{G} \alpha \mathrm{oC}$ is widely distributed throughout the brain, and its prevalence is estimated at more than $30 \%$ of Gol protein [60]. The modification might be important for the regulation of Go-mediated signaling, but the biological relevance and possible regulatory mechanisms remain unclear.

\section{Go Expression Pattern}

Go has a less ubiquitous expression pattern than Gi or Gs. Go, originally identified from bovine brain tissue, was estimated to compose around $0.5-1 \%$ of all brain membrane proteins. As expected Go is widely expressed in the central nervous system (CNS), including the retina and the olfactory bulb [61-63] as well as in the peripheral nervous system, including the superior cervical ganglia and sciatic nerve [64]. In addition, Go expression has been observed in heart tissue $[61,65-68]$ and in the endocrine system, including the pituitary gland and pancreatic islets. Go is expressed widely in the brain, however the regional distribution of Go protein is not homogeneous. High densities of Go protein have been observed in the frontal cortex, cerebellum, hypothalamus, hippocampus, and substantia nigra [69]. At the cellular level, high concentrations of Go protein were detected in synaptic-rich neuropils, such as the molecular layer of the cerebral cortex, neuropil of hippocampus, and posterior pituitary. Go was mainly distributed in cell bodies and neuritic cytoplasm as demonstrated in ultrastructural localization studies. Go protein was principally found on the cytoplasmic face of the plasma membrane lining the cell body and the neurites, especially at 'cell-to-cell' contacts. Go was also detected in the cytoplasmic matrix, between the endoplasmic reticulum and Golgi cisternae [70]. These findings strongly suggest that the Go protein is involved in transducing chemical signals at the synap- tic level and likely modulates synaptic functions by controlling the activity of effectors localized away from the synaptic membrane.

\section{Protein Stability and Expression during Development}

Changes in Go $\alpha$ protein expression were observed in the chick heart during embryonic development. A muscarinic agonist had little or no effect on heart rate 2.5 days in ovo, even though muscarinic receptors are already present on the cell membrane as measured by ligand binding of a muscarinic antagonist [71]. The expression level of Go $\alpha$ protein doubled in 1 day (day 3.5) and doubled again by the end of day 10 in ovo [65]. The muscarinic effect on adenylyl cyclase activity increased as a function of the Go $\alpha$ protein expression level. This developmental regulation of Go $\alpha$ protein was also observed in mammals $[66,72,73]$. In the feline heart, the concentration of Go $\alpha$ increases just after birth, remains elevated until postnatal day 10, and then gradually decreases [66]. Go $\alpha$ is detected in both atria and ventricles of rabbit, and interestingly, the concentration of Go $\alpha$ is higher in atria than in the ventricles [72]. Gol $\alpha$ is predominant in atrial samples, and there is no detectable Go $2 \alpha$ mRNA in atria or ventricles [73]. However, the developmental pattern of Go $\alpha$ protein expression in atria does not match absolutely with the pattern of mRNA expression.

Studies of neuroblastoma $\times$ glioma hybrid cells (NG108-15) demonstrated that Go protein expression undergoes a dynamic change that is dependent on the stage of differentiation [74]. Very little Go was detected in membrane preparations from undifferentiated NG10815 cells, while high levels of Go were observed after cells were induced to differentiate. Comparison of the expression levels of Go proteins in undifferentiated and differentiated neuroblastoma cells N1E-115 as well as in primary cultures of cerebellar granule cells, revealed that Go2 predominated in Go expression in undifferentiated neuroblastoma cells, whereas both isoforms, Gol and Go2 were expressed in differentiated cells. Moreover, Go1 is predominately expressed in well-differentiated cerebellar granule cells [75]. Studies of Go $\alpha$ turnover using pulse-chase labeling in neuroblastoma cells showed that the half-life of total Go protein increased from 28 to $58 \mathrm{~h}$ when neuroblastoma cells were differentiated. The halflife of Go reached $154 \mathrm{~h}$ in primary cultures of cerebellar granule cells. Each isoform of Go $\alpha$ exhibited similar degradation rates in the same cells at varying stages of differentiation; however, the rate of each isoform's synthesis varies in those cells and at different stages of differentiation [76]. This suggests that the rate of degradation of the 
Go protein is not a characteristic of the protein itself but rather dependent on the state of cell differentiation. The synthesis rate of Goo 1 is increased in differentiated cells while the rate for Goo 2 is decreased. The mechanisms that control differential expression of each isoform, including the regulation of the alternative splicing that generates both isoforms, require further study.

\section{Receptors Couple to Effectors through Go}

Heptahelical GPCRs represent the largest family of transmembrane receptors. GPCRs constitute the most common targets for therapeutic drugs and many of these receptors are coupled to their effectors through Go or Gi proteins. The human genome project revealed that there are $>400$ GPCR genes (excluding genes for odorant receptors) in the human genome [77]. Go has been shown to couple to many receptors, including muscarinic cholinergic receptors, GABAb receptors, $\alpha_{2}$-adrenergic receptors, and somatostatin receptors. In earlier studies, receptor coupling to Go was identified by receptorG-protein reconstitution, which assays the receptor ligand(s)-binding properties, the agonists stimulating GTPase activity, and those inhibiting adenylyl cyclase activity. Addition of Go proteins to a muscarinic receptor preparation enhanced the agonist's affinity to the receptors by at least 10 - to 20 -fold, and low concentrations of guanine nucleotides specifically reversed this effect [78, 79]. This result suggested that muscarinic receptors are coupled to their effectors by the Go protein. Similar experiments demonstrated that the $\mu$-opioid receptor is coupled to both $\mathrm{Gi}$ and Go [80]. In reconstitution experiments, purified Go proteins exhibit a similar efficiency as purified Gi proteins for coupling with most receptors tested. Reconstitution is a useful in vitro assay to demonstrate receptor-G-protein coupling, however, in vivo assays in cells or whole organisms (e.g. gene knockout animals) are required to verify receptor- $G$ protein functional coupling. PTX catalyzes the ADP ribosylation of Gi/Go $\alpha$ subunits and hence uncouples Go and Gi from their receptors, consequently disrupting Gi/Go signaling. Many receptors have been identified as Go or Gi coupled by PTX uncoupling, though to which member in this family they couple to could not be discriminated.

Somatostatin is a peptide hormone produced in the hypothalamus and peripheral endocrine $\delta$ cells. It can reduce voltage-dependent $\mathrm{Ca}^{2+}$ currents and lower intracellular free $\mathrm{Ca}^{2+}$ in pituitary cells in a reversible manner. Treatment of pituitary cells with PTX abolished the action of somatostatin on both $\mathrm{Ca}^{2+}$ currents and intracellular free $\mathrm{Ca}^{2+}$. Intracellular application of GTP $\gamma \mathrm{S}$ changed the effects of somatostatin from reversible to irreversible inhibition. Intracellular cAMP clamped at 100 $\mathrm{mM}$ in cells, a concentration two magnitudes greater than is needed for maximal activation of PKA, had no effect on either the action of somatostatin on $\mathrm{Ca}^{2+}$ currents or effect of GTP $\gamma S$ on the inhibition of $\mathrm{Ca}^{2+}$ currents by somatostatin [81]. This suggests that Go and/or Gi proteins are directly involved in cAMP-independent somatostatin receptor-mediated inhibition of voltage-dependent $\mathrm{Ca}^{2+}$ channels in endocrine cells. Furthermore, immunoprecipitation with anti-Go, -Gi1, and -Gi3 antibodies can precipitate the somatostatin receptor complex along with the $\mathrm{G}$ protein, suggesting that Go, Gi1, and Gi3 couple to somatostatin receptors [82].

Like somatostatin inhibition of voltage-dependent $\mathrm{Ca}^{2+}$ currents, opioid peptides and opiates inhibit neurotransmitter release, which is a $\mathrm{Ca}^{2+}$-dependent, PTXsensitive process. Pretreatment of neuroblastoma-glioma hybrid cells with PTX completely abolishes opioid inhibitory effects on the $\mathrm{Ca}^{2+}$ current. This inhibitory effect is restored by intracellular application of Gi and Go. However, Go (with or without the $\beta \gamma$ complex) is 10 times more potent than Gi protein in this restoration [83]. In dorsal root ganglion neurons, reconstitution experiments demonstrate that the Go protein also couples neuropeptide Y (NPY) receptors to $\mathrm{Ca}^{2+}$ channels [84]. Microinjection of antibodies and antisense oligonucleotides against $G$ protein subunits can specifically downregulate or block $G$ protein-signaling pathways in cells. This approach has been used in combination with functional assays, such as electrophysiological recording of $\mathrm{Ca}^{2+}$ currents, to identify receptors that are coupled to Go. Acetylcholine M4 muscarinic receptors couple to Gol $(\alpha 1 \beta 3 \gamma 4)$, while somatostatin receptors couple to Go2 $(\alpha 2 \beta 1 \gamma 3)$ as demonstrated by microinjection of antisense oligonucleotides into GH3 cells [85-87].

Recently, animals lacking both Go protein isoforms have been generated [88-90]. Studies of receptor signaling in tissues and cells derived from the Go knockout animals have provided direct genetic evidence to verify receptor coupling. Go couples opioid receptors to $\mathrm{N}$-type $\mathrm{Ca}^{2+}$ channels in dorsal root ganglion neurons [89]. In addition, M2 muscarinic receptors have been shown to regulate L-type $\mathrm{Ca}^{2+}$ currents in ventricular cardiac myocytes through Go [90]. In order to test receptor- $\mathrm{G}$ protein coupling in the native CNS environment, agonists of several Go/Gi-coupled receptors have been tested for their ability to enhance GTP $\gamma \mathrm{S}$ binding in mouse brain sec- 
tions from Go knockout and control animals. Studies have demonstrated that many receptors, including dopamine, serotonin, opioid, glutamine, and muscarinic receptors, couple effectively to their effectors through the Go protein in the CNS. Furthermore, dopamine $\mathrm{D}_{2}$ receptor populations achieve their high-affinity conformational state by coupling to $\mathrm{G}$ proteins, and they predominantly couple to Go proteins in the brain [46].

\section{Go-Mediated Signaling Transduction}

The signaling transduction mechanism of Go protein and its intracellular effectors have received intensive scrutiny. Go proteins, comprised of the $\alpha$ subunit and its $\beta \gamma$ moiety, regulate several intercellular effectors in their functional signaling pathways.

\section{Calcium Channels}

The inhibitory neurotransmitters, such as 5-HT, GABA, and noradrenaline, which reduce the duration of action potentials in dorsal root ganglion neurons, were identified before the discovery of $\mathrm{Gi}$ and Go proteins [91]. The reduction in action potential duration was demonstrated as result of the inhibition of voltage-gated $\mathrm{Ca}^{2+}$ channels by these neurotransmitters [92]. Since then, it has become evident that numerous hormones or neurotransmitters, including somatostatin and muscarinic agonists, suppress $\mathrm{Ca}^{2+}$ channel currents. Treatment of dorsal root ganglion neurons with PTX blocks noradrenaline and GABA-mediated inhibitory effects on $\mathrm{Ca}^{2+}$ channels. GTP $\gamma S$ irreversibly potentiates, while GDP $\beta S$ blocks the agonist-mediated inhibitory effects on $\mathrm{Ca}^{2+}$ channels $[93,94]$. These experiments demonstrated that G proteins, specifically PTX-sensitive Go or Gi subtypes, could modulate neuronal $\mathrm{Ca}^{2+}$ channel activity. Subsequently, many hormones and neurotransmitters acting on inhibitory receptors - including muscarinic acetylcholine, opioid, somatostatin, NPY, prostaglandin, adrenergic, and adenosine receptors - have been shown to inhibit $\mathrm{Ca}^{2+}$ channels through the PTX-sensitive Go/Gi $G$ protein subtypes [95]. In rat dorsal root ganglion neurons, NPY effectively suppressed the N-type $\mathrm{Ca}^{2+}$ currents, while PTX treatment could completely abolish this inhibition. Addition of purified bovine Go $\alpha$ subunits effectively restored the NPY modulation of $\mathrm{Ca}^{2+}$ currents while purified Gi1 $\alpha$ or Gi2 $\alpha$ had little or no effect [96]. Interestingly, the bradykinin inhibitory effects on $\mathrm{Ca}^{2+}$ currents in PTX-treated cells was only partially restored by the addition of either purified Go $\alpha$ or Gi2 $\alpha$, even at high concentrations. Complete restoration required the combination of both Go $\alpha$ and Gi2 $\alpha$ proteins. This suggests that Go and Gi2 proteins may couple to distinctive subpopulations of bradykinin receptors since Go nor Gi2 protein alone cannot compensate the loss of the other. The injection of anti-Go $\alpha$ antisense oligonucleotides into rat dorsal root ganglion neurons or into the pituitary neurosecretory GH3 cell line reduced the Go $\alpha$ protein levels and diminished $\mathrm{Ca}^{2+}$ channel inhibition by GABA, somatostatin, and carbachol $[85,97]$. In addition, injections of anti-Goo antibodies into rat sympathetic neurons reduced inhibition mediated by noradrenaline [98]. In mouse dorsal root ganglion neurons, opioids function through their receptors to suppress $\mathrm{N}$-type $\mathrm{Ca}^{2+}$ channels. Neurons lacking Go protein lose opioid inhibitory effects [89]. In ventricular cardiac myocytes, carbachol acts as a $\mathrm{M} 2$ muscarinic receptor agonist, thereby inhibiting L-type $\mathrm{Ca}^{2+}$ currents. This muscarinic inhibition of $\mathrm{Ca}^{2+}$ currents is completely missing in myocytes isolated from Go $\alpha$ gene knockout mice [90]. These findings suggest that the voltage-gated $\mathrm{Ca}^{2+}$ channel is an intracellular effector of the Go-signaling pathway.

\section{Potassium Channels}

The $\mathrm{K}^{+}$channel on the plasma membrane is also one of the intracellular effectors of Go-mediated signaling. This has been demonstrated in several systems by electrophysiological studies. An inward rectifying $\mathrm{K}^{+}$channel was first detected in frog skeletal muscles in 1949. Subsequently, its presence has been demonstrated in various cell types including egg, heart muscle, neurons in vertebrates as well as invertebrates [99]. In vertebrate cells, most of the resting membrane conductance has been attributed to inward $\mathrm{K}^{+}$channel activity. Owing to its physiological significance, the regulation of $\mathrm{K}^{+}$currents in heart muscle preparations and neurons received exhaustive attention. Binding of agonists to cardiac muscarinic acetylcholine and adenosine receptors slows pacemaker activity by activating $\mathrm{K}^{+}$channels. The $\mathrm{K}^{+}$currents in embryonic chick atrial cells were stimulated by acetylcholine as shown by electrophysiological recordings [100]. Atropine, an antagonist of muscarinic receptors, effectively prevented the induction of $\mathrm{K}^{+}$conductance by acetylcholine. This suggests acetylcholine action was receptor-mediated. In fact, the acetylcholine-induced $\mathrm{K}^{+}$ current is GTP-dependent. Without GTP in the pipettes, cells did not show any response to acetylcholine. Cells pretreated with PTX lost acetylcholine-potentiated $\mathrm{K}^{+}$ currents. Similar mechanisms have been found in neural cells. In hippocampal pyramidal cells, serotonin and the 
selective GABAb agonist baclofen hyperpolarize cells by increasing $\mathrm{K}^{+}$channel conductance. The 5-HT and baclofen responses are completely ablated in PTX-treated cells. Addition of a stable form of GDP, GDP $\beta$ S, to cells reduced responses to 5-HT and baclofen, while addition of GTP $\gamma$ S, a non-hydrolysable GTP which binds to and activates $\mathrm{G}$ proteins, mimicked the action of $5-\mathrm{HT}$ and baclofen. This suggests that Go and Gi proteins mediate the effects of serotonin and GABAb receptor signaling on $\mathrm{K}^{+}$channels in hippocampal pyramidal cells [101]. Since Go is the predominant form of the PTX-sensitive G proteins in the brain, Go protein regulation of $\mathrm{K}^{+}$channels would be logical. A reconstitution assay combined with single channel recording experiments provided convincing evidence for this assumption [102]. Both purified bovine brain Go proteins as well as a recombinant form of Go $\alpha$ proteins activated $\mathrm{K}^{+}$channels in membrane patches excised from hippocampal pyramidal cells.

Many receptors including the somatostatin receptor, purinergic receptor, opioid receptor, and 5-HT receptor have been identified in heart muscle tissue and in peripheral and central neurons that activate $\mathrm{K}^{+}$channels through Go and/or Gi proteins. Ligand receptor binding activates heterotrimeric $\mathrm{G}$ proteins which exchange GDP for GTP on the $\mathrm{G} \alpha$ subunit. The subsequent dissociation of the trimeric complex releases the G $\beta \gamma$ subunit and the G $\alpha-G T P$ complex, which are both capable of signaling to downstream effectors. Purified and recombinant G $\beta \gamma$ subunits can activate $\mathrm{K}^{+}$channels when applied to the cytosolic side of excised $\mathrm{K}^{+}$channel-containing membrane patches [103105]. The binding of G $\beta \gamma$ subunits at the $\mathrm{N}$ - and C-termini of $\mathrm{K}^{+}$channels may be the mechanism of ligand-gating [106]. It seems that both Go $\alpha$ and G $\beta \gamma$ subunits can activate $\mathrm{K}^{+}$channels. However, G $\beta \gamma$ subunits have less specificity for activating $\mathrm{K}^{+}$channels; different combinations of the $\beta$ and $\gamma$ subunits can activate $\mathrm{K}^{+}$channel almost equipotently [107]. It appears that the Go $\alpha$ subunit may act as a chaperone for G $\beta \gamma$ subunit receptor-targeting and $\mathrm{K}^{+}$channel specificity. Expression of Gil or Gi3 $\alpha$ subunits in Xenopus oocytes reduced excessive G-protein-regulated inwardly rectifying $\mathrm{K}^{+}$(GIRK) activity. The $\alpha$ subunits can also physically bind to GIRK channels [108], suggesting that the $\alpha$ subunits of Go/i may also be involved in channel gating. The exact mechanism by which Go proteins gate $\mathrm{K}^{+}$channels in cardiac atrial cells and neurons requires further investigation.

\section{Sodium Channels}

In addition to the regulation of $\mathrm{Ca}^{2+}$ and $\mathrm{K}^{+}$channels, Go proteins may also regulate $\mathrm{Na}^{+}$channels in cells. De- polarization of the cell membrane in rat brainstem synaptoneurosomes activates Go protein and modulates $\mathrm{Na}^{+}$ channel gating $[109,110]$. In addition, cross-linking and co-immunoprecipitation experiments in depolarized brainstem synaptoneurosomes demonstrated a direct physical interaction between Go proteins and the $\mathrm{Na}^{+}$ channel $\alpha$ subunit [111]. In mouse mandibular gland duct cells, increasing cytosolic $\mathrm{Na}^{+}$concentration inhibits $\mathrm{Na}^{+}$ currents. This effect is blocked by the addition of GDP $\beta S$, treatment with PTX, or antibodies against the Goo protein $[112,113]$. These studies indicate that active Go may mediate the effects of cytosolic $\mathrm{Na}^{+}$on $\mathrm{Na}^{+}$channels. Interestingly, Gi proteins can mediate the cytosolic anions inhibitory effects on $\mathrm{Na}^{+}$channels. However, receptors responsible for this action have not been identified.

\section{Adenylyl Cyclase}

Although Go protein was originally identified as an additional form of Gi protein, a difference in their inhibitory effect has been observed in reconstituted adenylyl cyclase assay systems. The addition of purified GTP $\gamma S$ bound Gi $\alpha$ inhibits the stimulation of adenylyl cyclase induced by Gs, while the addition of purified GTP $\gamma S$ bound Go $\alpha$ proteins (Gol) has no inhibitory effect on adenylyl cyclase activity [114]. Studies of constitutively active mutants of Gi and Go on adenylyl cyclase also support this finding [115]. The constitutively active mutants of the Gi $\alpha$ (1, 2 and 3) subunits inhibit cAMP accumulation in stably transfected NIH-3T3 cells, while the active Gol $\alpha$ mutant lacks inhibitory effects on adenylyl cyclase activity. However, the other isoform of Go, Go2 $\alpha$ can inhibit adenylyl cyclase similar to the Gi $\alpha$ subunits in reconstituted adenylyl cyclase assay systems [116]. Interestingly, recent studies have demonstrated that Go $\alpha$ directly interacts with cAMP-dependent protein kinase (PKA) through its GTPase domain. This interaction did not inhibit the kinase function of PKA but interfered with the nuclear translocation of PKA, sparing its cytosolic func-

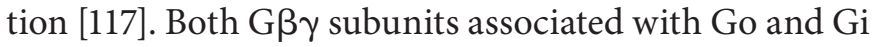
proteins showed equal efficiency in inhibiting adenylyl cyclase activity. It is technically difficult to demonstrate inhibitory effects on adenylyl cyclase. The assay requires a large amount of highly purified components, including receptors, $G$ proteins, and adenylyl cyclase. The proper lipid modification of the $\mathrm{G} \alpha$ and $\gamma$ subunits is also required. Furthermore, there are more than nine different forms of adenylyl cyclase with selective responses. Finally, the inhibitory effects need to be observed in an activated background from which differences are often not profound. 


\section{$D A G$ Kinase and Gq-PLC- $\beta$}

As in mammalian species, Go protein is highly expressed in the neurons of C. elegans. Serotonin signaling controls several C. elegans behaviors, including locomotion, feeding, and egg laying. Go was identified genetically as the transducer for serotonin-controlled behavioral effects in C. elegans $[118,119]$. Genetic studies demonstrated that animals that lost Go $\alpha$ or lost diacylglycerol kinase (DAG kinase) shared the same phenotype $[120,121]$. Furthermore, the phenotype caused by constitutive activation of Goo in C. elegans was suppressed by mutations in DAG kinase. This suggests that Go $\alpha$ acts upstream of DAG kinase in the serotonin-signaling pathway. Mutants of Gq and mutants of PLC- $\beta$ share the same phenotype, which is an opposite phenotype of animals lacking Go or DAG kinase. At the molecular level, activation of the Gq, PLC- $\beta$ pathway results in production of diacylglycerol (DAG), while the activation of the Go-mediated pathway reduces levels of DAG in cells. Animals lacking Go, goa-1 mutants, accumulated high levels of DAG-binding protein UNC-13 at motor neuron nerve terminals, suggesting Go decreases the abundance of UNC-13 at release sites [121]. The Go-mediated pathway antagonizes the Gq-PLC- $\beta$, DAG-signaling pathway and plays an important role in controlling worm movement and olfactory adaptation $[122,123]$. However, the precise mechanism has not been elucidated and unlike mammals that have two isotypes of Go protein, there is only a single orthologue of Go encoded by the goa-1 gene in the C. elegans. The role of Go in antagonizing the Gq pathway in C. elegans is not known to occur in mammalian systems and therefore needs to be addressed.

\section{Mitogenic Activation Signaling}

Evidence for Go protein's involvement in mitogen activation primarily comes from studies using constitutively activated mutants $[124,125]$. Microinjection of a constitutively active, GTPase-deficient form of Go $\alpha$ into Xenopus oocytes resulted in resumption of the cell cycle after meiotic maturation of the oocytes. Furthermore, the expression of a constitutively active form of Go $\alpha$ in the mammalian cell line NIH-3T3 fibroblasts, lead to cellular transformation. Oocyte maturation mediated by active Go $\alpha$ occurs through the activation of protein kinase $\mathrm{C}$ and c-mos, while the transforming capability of Go $\alpha$ in NIH-3T3 fibroblasts is protein kinase $\mathrm{C}$ independent. Microinjection of anti-Go antibodies into Chinese hamster lung fibroblast CCL39 cells inhibited thrombin receptor-induced calcium signals and DNA synthesis, suggesting that Go protein could mediate mitogenic signal- ing [126]. In M1 muscarinic receptor transfected Chinese hamster ovary $(\mathrm{CHO})$ cells, application of an M1-receptor agonist resulted in PTX-sensitive, PKC-dependent MAPK activation. In PTX-treated cells, only a PTX-insensitive mutant of Go $\alpha$ could restore the M1 muscarinic receptor-mediated MAPK activation, whereas the PTX-insensitive $\alpha$ subunit mutants of Gi1, Gi2, and Gi3 could not [127]. Using Go $\alpha$ as bait in a yeast two-hybrid screen, rap1GAPII, a GTPase-activating protein for the small GTPase Rap1, and several other proteins including Gz-GAP and RGS17, were shown to physically interact with Go protein [128]. In a transfected PC12 cell system, expression of Go $\alpha$ results in the upregulation of Rap1 and leads to an increase in the activated state of the mitogenactivated kinase 2. Expression of the active Q to L Go $\alpha$ mutant in NIH-3T3 cells resulted in cellular transformation through activation of the protein kinase Src and subsequent activation of the signal transducer and activator of transcription 3 (Stat3), but not of the MAP kinases, suggesting that other mechanisms may be involved [129]. In neuro2A cells, activation of CB1 cannabinoid receptors mediates neurite outgrowth. Overexpression of Go $\alpha$ in neuro2A cells reduces the stability of raplGAPII, which results in the activation of Rap1 [130]. Activation of Rap1 leads to the activation of Src and Stat 3 that mediate gene expression that promotes neurite outgrowth [131].

Other lines of evidence suggest that a mechanism independent of Rap1 may activate MAPK through Go $\alpha$ signaling. Expression of an active mutant of $\mathrm{Go} \alpha$ in $\mathrm{CHO}$ cells is not sufficient to induce MAPK activation but greatly potentiates the MAPK response to epidermal growth factor stimulation. The active Go $\alpha$ mutant can activate the B-Raf kinase and MAPK through protein kinase C, a PI3K-dependent mechanism [132]. Furthermore, expression of an active Go $\alpha$ mutant can abolish the activation of Rap1 induced by EGF, suggesting the activation of MAPK activity by Go $\alpha$ is independent of Rap1 in this cell system [133]. Since most results were obtained by transfection experiments with an active mutant Go $\alpha$, activation of the MAPK pathway or STAT3 in the body remains to be explored. Interestingly, several lines of evidence suggest that the G $\beta \gamma$ complex is also involved in PTX-sensitive, MAPK activation [134, 135]. The role of Go $\alpha$ and its $\beta \gamma$ subunit in the modulation of the MAPK pathway still remains unclear.

\section{PI4-Kinase - Rho}

Go protein not only regulates the intracellular effectors at the cytoplasmic membrane but also controls secretory granule movement by regulating the small GTPase 
Rho and phosphatidylinositol 4-kinase (PI4-kinase) activity. The identification of Go protein as a chromaffin cell granule membrane associated protein by PTX ADP ribosylation suggested a possible role for Go protein in regulating exocytosis [136]. In addition, the Go $\alpha$ subunit was indicated to be directly involved in the control of exocytosis in pancreatic $\beta$ cells [137]. Mastoparan, a tetradecapeptide that selectively activates $\mathrm{Gi}$ and Go proteins, inhibits the $\mathrm{Ca}^{2+}$-evoked reorganization of the cortical actin network in chromaffin cells. Specific anti-Goo antibodies or peptides derived from the $\mathrm{C}$ terminus of Go $\alpha$ selectively reversed the effect of mastoparan on the actin network, suggesting Go protein's involvement [138, 139]. Furthermore, mastoparan-stimulated actin-network reorganization is PI4-kinase-dependent. Antibodies against Goo specifically inhibited mastoparan-stimulated PI4-kinase activity. Clostridium botulinum C3 exoenzyme, which specifically inhibits the small GTPase Rho activity, completely blocked the activation of PI4-kinase by mastoparan [140]. These results suggest that Rho and PI4-kinase are involved in the pathway by which Go $\alpha$ controls reorganization of the actin network and thus the exocytosis process in chromaffin cells.

\section{Vesicular Transporters}

As described above, Go proteins modulate Rho and PI4-kinase to control reorganization of the actin network. Recent studies suggest that regulation of Rho and PI4-kinase by Go may modulate neuronal excitability by controlling neurotransmitter uptake and secretion. Biochemical analysis has demonstrated that Go protein is present on secretory granules or synaptic vesicles [141]. In the rat pheochromocytoma PC12 cells and in human pancreatic neuroendocrine tumor BON cells, GTP analogs and AlF4-, which both activate G proteins, downregulated vesicular transporters. This effect was sensitive to treatment with pertussis toxin, suggesting Gi or Go protein involvement $[142,143]$. Inhibition of vesicular transporters was suppressed by Go $\alpha$-specific antibodies and mimicked by purified activated Go $\alpha 2$. Analysis of vesicular glutamate transporter activity in the mouse brain showed that Go2 exerts its action by affecting the chloride dependence of vesicular glutamate transporters. Glutamate uptake by vesicles isolated from Go2 knockout mice, but not from other Go/Gi knockouts, completely lost chloride activation [144]. C. botulinum C3 exoenzyme, which inhibits Rho activity, increased both uptake and secretion of glutamate in cultivated mouse astrocytes. The upregulation of glutamate transporters is responsible for the enhanced glutamate uptake. In addi- tion, C. botulinum $\mathrm{C} 3$ exoenzyme promotes the $\mathrm{Ca}^{2+}$-dependent exocytosis process [145]. Taken together, Go protein may mediate a novel signal cascade to control neurotransmitter or hormone storage and release, which in turn would modulate neuronal and endocrine cell excitability. The signaling mechanism, by which factors or receptors either on the cell surface or within a novel intercellular location control the effect of Go protein on vesicular transporter activity, remains to be elucidated.

\section{Go Protein Function}

Considering that $\mathrm{Go}$ is the most abundant $\mathrm{G}$ protein in the brain, the functional importance of Go signaling in the CNS is evident but largely undefined. The Gi/o proteins couple to serotonin, dopamine, GABAb, opioid, glutamate, and cholinergic receptors among others. Studies of mice lacking both isoforms of Go $\alpha$ have reported several neurological deficits, including tremors, seizures, and a repetitive turning behavior $[89,90]$. In addition to the animals having poor motor coordination, Go $\alpha$ knockouts are also hyperactive and exhibit abnormal exploratory behavior as well as hyperalgesia when subjected to a hot plate test [89]. Other knockout mice of the Gi/o family of $\mathrm{G}$ proteins do not display any observable neurological deficiencies.

\section{GAP-43 and Neuronal Development}

Go protein's localization to neuronal synapses and growth cones alludes to a role for Go in transducing signals from neurotransmitters and hormones as well as in chemosensing during axonal outgrowth. The ability of GAP-43 to enhance binding of GTP to Go protein in the distal tips of growth cones suggested that Go may have a role in neurite extension [146]. GAP-43 is highly expressed in the growth cones of developing and regenerating neurons [147-150]. Unlike GPCRs, GAP-43 is a cytosolic protein found at the leading edge of growth cones, however, like GPCRs, GAP-43 can promote guanine nucleotide exchange by accelerating GDP release from Go [151]. Transfection of an activated Go1 in NGF differentiated PC12 cells doubled the number of neurite outgrowths per cell, and this action occurred via inhibition of protein kinase $\mathrm{C}$ and modulation of intracellular $\mathrm{Ca}^{2+}[152,153]$. In C. elegans, misdirected neuronal migration appears in serotonin-deficient mutants as well as in the Go protein homolog, goa-1, loss-of-function mutants [154]. Double loss-of-function analysis suggests that goa-1 is an effector of serotonin signaling, and in accordance, the N-type 
$\mathrm{Ca}^{2+}$ channel homolog, unc-2, appears to act downstream of goa-1 in neuronal guidance signaling [154]. These studies agree that Go-signaling is utilized in neuronal outgrowth. Studies of developing neurons from the moth (Manduca sexta) found that Go-mediated signaling could inhibit neuronal migration by modulating intracellular $\mathrm{Ca}^{2+}$ levels, and chelation of the intracellular $\mathrm{Ca}^{2+}$ would result in misguidance of neurons [155]. A body of literature identifies intracellular $\mathrm{Ca}^{2+}$ levels as a key modulator of axonal extension, cell targeting, cytoskeleton dynamics, and synaptic plasticity [156]. A possible role for Go protein in neuronal motility may be to translate gradients of extracellular factors into attractant or repellent signals by altering $\mathrm{Ca}^{2+}$ homeostasis.

The role of the Go protein homolog in Drosophila, Go $447 \mathrm{~A}$, has been broadly studied in the CNS and during development. Goo47A is the only substrate for PTX in fruit flies. PTX-labeling as well as immunological data have shown that Go protein expression increases at the 10-hour embryonic stage, coinciding with the commencement of neuronal axon development $[157,158]$. Interestingly, elevated levels of Go protein have been reported in mutants having reduced short-term memory [159]. In behavioral studies, exclusive PTX expression in mushroom body neurons led to a reduction in associative learning ability in flies, and the effect appeared independent of the rutabaga memory mutation, which confers a defective type I adenylyl cyclase [160]. The other memory mutants-dunce, a cAMP-phosphodiesterase, and turnip, which affects protein kinase $\mathrm{C}$ activation - are also regulators of signal transduction, and it appears Go protein's observed upregulation is compensatory to these mutations [159]. The Drosophila Go homolog has also been shown to play a role in the polarization of sensory organ precursor cells [161]. Simply, Go protein transduces signals from the Frizzled receptor, which directs the asymmetric distribution of effectors and establishes the axis for cell polarization [162]. These studies depict Go protein as a versatile component in neural embryogenesis, learning and memory, and sensory organ development, though our understanding of the mechanisms and effectors involved in Go signaling remains incomplete.

\section{Alzheimer's Disease}

Go protein may be involved in the pathogenesis of Alzheimer's disease (AD). The progressive neurodegeneration in AD is pathologically characterized by the presence of senile plaques, neurofibrillary tangles, and the subsequent loss of neurons. Genes for APP, Presenilin 1 (PS1), and Presenilin 2 (PS2) have been identified as her- itable familial AD (FAD) genes. A physical interaction between APP and Go protein has been demonstrated in synthetic vesicle preparations $[163,164]$. The APP FAD mutants, V642I/F/G, can specifically activate Go protein in the absence of ligand [165]. This effect can be blocked by PTX treatment or by application of monoclonal antibodies against the APP cytoplasmic domain. Furthermore, these and other APP mutants have been shown to induce apoptosis in neuronal cell culture $[166,167]$. The induction of apoptosis by these mutants as well as by amyloid- $\beta(A \beta)$ peptides is mediated through Go signaling or the p21-activated kinase (PAK) $3[168,169]$. PS1 has also been shown to directly interact with Go but not with Gi proteins [170]. In addition, PS2 protein can induce apoptosis through a PTX-sensitive pathway in PC12 cells [171]. These in vitro studies suggest that Go may be involved in neuronal loss in $\mathrm{AD}$ through apoptotic signaling mediated by either a pathogenic substrate, $A \beta$, or a mutant APP or PS-1/2. The extent to which apoptosis contributes to the cognitive decline in $\mathrm{AD}$ is debated, although evidence of increased DNA fragmentation and activation of multiple caspases, including -3 and -9 , have been shown in the presence of $A \beta$ peptides [172]. A defined biological function for a possible APP or PS1/2 receptor-Go complex and the relationship between Go and the pathogenesis of $\mathrm{AD}$ in vivo remain to be established.

\section{Parkinson's Disease}

The role of Go in Parkinson's disease (PD) pathogenesis has not been established. PD is a chronic, progressive neurodegenerative disorder that results primarily from the loss of dopaminergic neurons in the substantia nigra. Decreased dopaminergic signaling to the basal ganglia manifests itself as dysregulated movement in patients. The inhibitory $D_{2}$-like dopamine receptors $\left(D_{2}, D_{3}\right.$, and $\mathrm{D}_{4}$ ) are coupled to the Gi/o family of $\mathrm{G}$ proteins. Our group has shown that the majority of the effects of $\mathrm{D}_{2}$-like receptor signaling are mediated specifically by the Go protein [46]. Dopamine has shown to have both neurotoxic and neuroprotective effects in various cell types through $\mathrm{D}_{2}$ receptor signaling [173]. Further study will be necessary to determine if the $\mathrm{D}_{2}$ receptor-Go protein-signaling pathway could induce toxicity to neurons in PD.

\section{Schizophrenia}

Schizophrenia is a psychiatric disorder whose symptoms include delusional and disorganized thought, catatonic behavior, and sensory hallucinations. Unlike neurodegenerative diseases, schizophrenia is difficult to define due to the apparent comorbidity with other mental ill- 
nesses, inconsistency of symptoms, and lack of neuropathological hallmarks. Much research has been focused on the imbalance of neurotransmission. In the earliest studies of $\mathrm{G}$ proteins and schizophrenia, PTX labeling of brains uncovered a decreased level of $\mathrm{Gi} / \mathrm{o}$ proteins in the left side of the hippocampus and putamen of schizophrenics $[174,175]$. Go protein was specifically reduced across the hippocampus and caudate head of the right hemisphere in schizophrenic patients [176]. Dopaminergic hyperactivity in mesolimbic regions is prevalent in the schizophrenic brain, and thus $\mathrm{D}_{2}$-coupled signaling machinery, such as Go, are likely candidates for downregulation in regions with dopaminergic innervation. Further analysis of schizophrenic brains has shown decreased Gi/ $\mathrm{o}$ and Gq protein levels in the left side of the superior temporal cortex versus non-diseased brains, and interestingly, significantly lower levels of Gi/o protein were detected in the amygdala and nucleus accumbens of the paranoid schizophrenic subtype than in the disorganized subtype [177]. Recently, mutational analysis in 175 unrelated schizophrenics revealed a missense mutation in Go $\alpha$ protein, ATG $\rightarrow$ ACG (M129T), which significantly correlated with schizophrenic patients albeit with a low allele frequency ( 0.031 vs. 0.006 control) [178]. These findings are indicative of deviant signaling in the schizophrenic brain. How Go protein compensates or contributes to signaling dysfunction is not clear, and it will be important to determine whether regional changes in neurotransmission can mirror changes in $\mathrm{G}$ protein function and expression.

\section{Visual Signal Transduction}

Visual signal transduction is one of the best-characterized signaling cascades in the body. Retina bipolar cells are retinal interneurons that receive and integrate glutamatergic input from photoreceptors, and transmit these signals to ganglion neurons. Visual information is segregated into parallel ON and OFF pathways at the bipolar cell level through two types of bipolar neurons, ON and OFF. This is critical for detecting weak contrast as well as rapid changes in light intensity [179]. The ON bipolar cells become depolarized, and the OFF bipolar cells hyperpolarized when photoreceptors receive photon stimuli. The majority of bipolar cells are the ON-type bipolar cells. The glutamate receptor (mGluR6) is expressed restrictively in ON-type bipolar cells and serves as their primary postsynaptic receptor [180]. The b-wave in electroretinogram (ERG) recordings which reflects ON bipolar depolarization, is completely missing in mice lacking mGluR6, suggesting that mGluR6 is the receptor for synaptic transmission in ON bipolar cells [181]. Go protein is expressed in bipolar cells that also express mGluR6 [62]. Similar to mGluR6 knockout mutants, mice lacking the Go $\alpha$ protein also have a no b-wave phenotype, suggesting Go protein couples mGluR6 for signal transduction [182]. Furthermore, analysis of subtype-specific Go knockout mice we have generated demonstrates that the Gol $\alpha$ protein is specific for mGluR6-mediated signal transduction in retinal ON bipolar cells [183]. However, the downstream effectors and the signaling mechanism have yet to be elucidated.

\section{Vagal Regulation in Heart}

In the heart, Go protein is preferentially expressed in the atrium [72]. Detection of Go protein has also been observed in peripheral neurons and in granules of atrial endocrine cardiomyoctyes [68]. Studies of Go protein knockout mice have revealed that Go signaling controls muscarinic regulation of L-type $\mathrm{Ca}^{2+}$ channels in the heart [90]. $\mathrm{Ca}^{2+}$ currents in myocytes from control mice had a reduction in conductance after treatment with the muscarinic agonist, carbachol, whereas myocytes from Go $\alpha(-/-)$ mice were significantly unaltered. In addition, recent studies have also shown reduced effectiveness of muscarinic agonists in lowering heart rate in addition to decreased heart rate variability in Goo-deficient hearts [184]. These studies show that Go protein is responsible for certain negative chronotropic effects of parasympathetic stimulation in the heart. This mechanism seems to be independent of the $\mathrm{I}_{\mathrm{KACh}}$ channel [90]. The inability of Go protein-deficient animals to inhibit $\mathrm{Ca}^{2+}$ channel conductance at the plasma membrane may alter intracellular $\mathrm{Ca}^{2+}$ levels, which are critical to the induction of contraction. In fact, a transgenic animal expressing the constitutively active Q205L G $\alpha$ o mutant in the heart has recently shown increased expression of L-type $\mathrm{Ca}^{2+}$ channels and enhanced contractility [185]. Interestingly, enhanced phosphorylation of ryanodine receptor 2 and phospholamban was also observed in these hearts, an effect that allows greater $\mathrm{Ca}^{2+}$ storage in the sarcoplasmic reticulum and consequently more robust contractility. The mechanism or Go subunits responsible for these downstream effects remains unclear.

\section{Conclusion}

\section{Proposed Model of Signaling (fig. 3)}

As a signaling transducer with a high level of expression in the CNS, Go protein has received intensive attention. Great progress has been made in exploring the func- 
Fig. 3. Model of Go protein-mediated signal transduction.

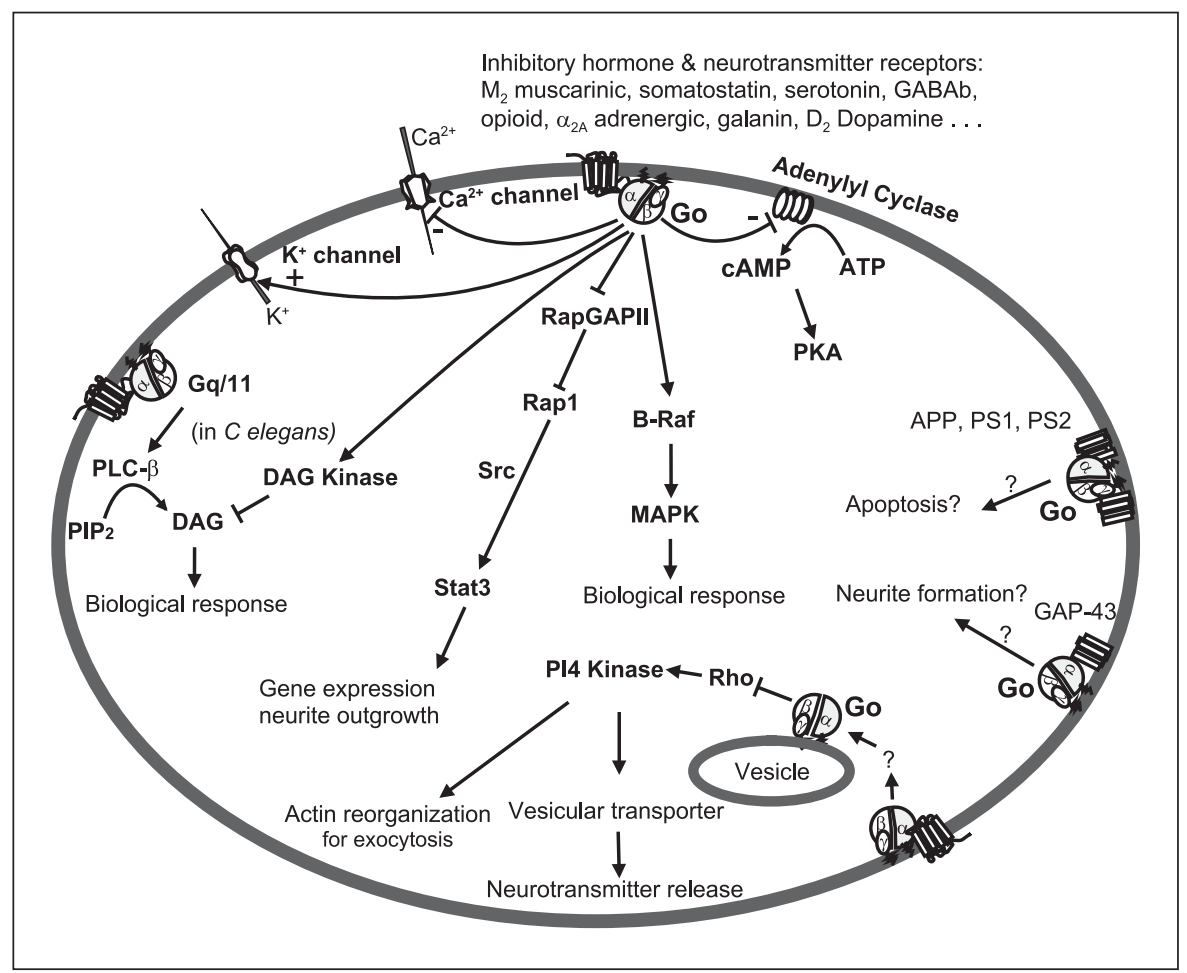

tional role of Go protein in the body and in revealing the mechanism for its actions. Among the PTX-sensitive Gi/ Go family members, study of Go protein function is of special interest for several reasons. In contrast to Gi proteins, which are expressed fairly ubiquitously, the expression of Go is restricted in the central and peripheral nervous systems, endocrine cells, and cardiomyocytes. By various means in vitro and in vivo, including biochemical reconstitution, electrical cell recording, and whole animal genetic studies, Go protein has been shown to interact with many neurotransmitter and hormone GPCRs. Besides coupling to the classic seven-transmembrane receptors, Go also associates with GAP-43 and the APP, indicating that Go protein may possess novel neurological functions in the body.

Several effectors with which Go protein interacts have been identified. Agonist-mediated activation of Go protein inhibits the voltage-gated L-type and N-type $\mathrm{Ca}^{2+}$ channel currents and potentiates $\mathrm{K}^{+}$channel currents and possibly $\mathrm{Na}^{+}$channel currents as well. Go2 protein can inhibit adenylyl cyclase activity in vitro. Activation of the Go pathway in C. elegans antagonizes the Gq-DAGsignaling pathway by activating DAG kinase. Go proteinmediated signaling may interact with MAP kinase or STAT to modulate cellular functions. In addition, Go protein regulates Rho and PI4-kinase in controlling the reorganization of the actin network or in activating neurotransmitter vesicular transporters. Great progress has been made in exploring the signal mechanism of Go since its discovery two decades ago. However, many important questions still need to be answered including identification of effectors of the Go-mediated signaling pathways, as well as its role in the pathogenesis of disease. Addressing the physiological role of Go in the body, especially in the CNS, where Go protein was first identified, will be a central issue for Go protein research in the future.

\section{Acknowledgement}

This study was supported by research grant DK069771 (M.J.) from the National Institute of Diabetes and Digestive and Kidney Diseases. 


\section{References}

- Birnbaumer L, Pohl SL, Rodbell M, Sundby F: The glucagon-sensitive adenylate cyclase system in plasma membranes of rat liver. VII. Hormonal stimulation: reversibility and dependence on concentration of free hormone. J Biol Chem 1972;247:2038-2043.

2 Ross EM, Gilman AG: Resolution of some components of adenylate cyclase necessary for catalytic activity. J Biol Chem 1977;252: 6966-6969.

-3 Gilman AG: G proteins: transducers of receptor-generated signals. Annu Rev Biochem 1987;56:615-649.

$\checkmark 4$ Fung BK, Hurley JB, Stryer L: Flow of information in the light-triggered cyclic nucleotide cascade of vision. Proc Natl Acad Sci USA 1981;78:152-156.

5 Moss J, Manganiello VC, Vaughan M: Substrate and effector specificity of a guanosine 3',5'-monophosphate phosphodiesterase from rat liver. J Biol Chem 1977;252:52115215.

6 Gill DM, Meren R: ADP ribosylation of membrane proteins catalyzed by cholera toxin: basis of the activation of adenylate cyclase. Proc Natl Acad Sci USA 1978;75:30503054.

7 Cassel D, Pfeuffer T: Mechanism of cholera toxin action: covalent modification of the guanyl nucleotide-binding protein of the adenylate cyclase system. Proc Natl Acad Sci USA 1978;75:2669-2673.

8 Katada T, Amano T, Ui M: Modulation by islet-activating protein of adenylate cyclase activity in C6 glioma cells. J Biol Chem 1982; 257:3739-3746

-9 Katada T, Ui M: Direct modification of the membrane adenylate cyclase system by isletactivating protein due to ADP ribosylation of a membrane protein. Proc Natl Acad Sci USA 1982;79:3129-3133.

10 Codina J, Hildebrandt J, Iyengar R, Birnbaumer L, Sekura RD, Manclark CR: Pertussis toxin substrate, the putative Ni component of adenylyl cyclases, is an alpha beta heterodimer regulated by guanine nucleotide and magnesium. Proc Natl Acad Sci USA 1983;80:4276-4280.

11 Bokoch GM, Katada T, Northup JK, Hewlett EL, Gilman AG: Identification of the predominant substrate for ADP ribosylation by islet-activating protein. J Biol Chem 1983; 258:2072-2075

12 Neer EJ, Lok JM, Wolf LG: Purification and properties of the inhibitory guanine nucleotide regulatory unit of brain adenylate cyclase. J Biol Chem 1984;259:14222-14229.

13 Sternweis PC, Robishaw JD: Isolation of two proteins with high affinity for guanine nucleotides from membranes of bovine brain. J Biol Chem 1984;259:13806-13813.

14 Milligan G, Klee WA: The inhibitory guanine nucleotide-binding protein $(\mathrm{Ni})$ purified from bovine brain is a high affinity GTPase. J Biol Chem 1985;260:2057-2063.
15 Itoh H, Kozasa T, Nagata S, Nakamura S, Katada T, Ui M, Iwai S, Ohtsuka E, Kawasaki $\mathrm{H}$, Suzuki K, et al: Molecular cloning and sequence determination of cDNAs for alpha subunits of the guanine nucleotide-binding proteins Gs, Gi, and Go from rat brain. Proc Natl Acad Sci USA 1986;83:3776-3780.

16 Ferguson KM, Higashijima T, Smigel MD, Gilman AG: The influence of bound GDP on the kinetics of guanine nucleotide binding to G proteins. J Biol Chem 1986;261:73937399 .

17 Strittmatter SM, Valenzuela D, Sudo Y Linder ME, Fishman MC: An intracellular guanine nucleotide release protein for G0. GAP-43 stimulates isolated alpha subunits by a novel mechanism. J Biol Chem 1991;266: 22465-22471.

18 Strittmatter SM, Valenzuela D, Vartanian T, Sudo Y, Zuber MX, Fishman MC: Growth cone transduction: Go and GAP-43. J Cell Sci Suppl 1991;15:27-33.

19 Cismowski MJ, Takesono A, Ma C, Lizano JS, Xie X, Fuernkranz H, Lanier SM, Duzic E: Genetic screens in yeast to identify mammalian nonreceptor modulators of G-protein signaling. Nat Biotechnol 1999;17:878883.

20 Cismowski MJ, Ma C, Ribas C, Xie X, Spruyt M, Lizano JS, Lanier SM, Duzic E: Activation of heterotrimeric G-protein signaling by a ras-related protein. Implications for signal integration. J Biol Chem 2000;275:2342123424.

21 Kemppainen RJ, Behrend EN: Dexamethasone rapidly induces a novel ras superfamily member-related gene in AtT-20 cells. J Biol Chem 1998;273:3129-3131.

22 Graham TE, Prossnitz ER, Dorin RI: Dexras1/AGS-1 inhibits signal transduction from the Gi-coupled formyl peptide receptor to Erk-1/2 MAP kinases. J Biol Chem 2002 277:10876-10882.

23 Takesono A, Zahner J, Blumer KJ, Nagao T, Kurose $\mathrm{H}$ : Negative regulation of alpha-2adrenergic receptor-mediated $\mathrm{Gi}$ signalling by a novel pathway. Biochem J 1999;343 Pt 1: 77-85

24 Siderovski DP, Diverse-Pierluissi M, De Vries L: The GoLoco motif: a Galphai/o binding motif and potential guanine-nucleotide exchange factor. Trends Biochem Sci 1999;24:340-341.

25 De Vries L, Zheng B, Fischer T, Elenko E, Farquhar MG: The regulator of $\mathrm{G}$ protein signaling family. Annu Rev Pharmacol Toxicol 2000;40:235-271.

26 Diverse-Pierluissi MA, Fischer T, Jordan JD, Schiff M, Ortiz DF, Farquhar MG, De Vries L: Regulators of $\mathrm{G}$ protein signaling proteins as determinants of the rate of desensitization of presynaptic calcium channels. J Biol Chem 1999;274:14490-14494.
27 Xu X, Zeng W, Popov S, Berman DM, Davignon I, Yu K, Yowe D, Offermanns S, Muallem S, Wilkie TM: RGS proteins determine signaling specificity of Gq-coupled receptors. J Biol Chem 1999;274:3549-3556.

$>28$ Hoffmann M, Ward RJ, Cavalli A, Carr IC, Milligan G: Differential capacities of the RGS1, RGS16 and RGS-GAIP regulators of G protein signaling to enhance alpha- $2 \mathrm{~A}$-adrenoreceptor agonist-stimulated GTPase activity of G(o1)alpha. J Neurochem 2001;78: 797-806

29 Murtagh JJ Jr, Eddy R, Shows TB, Moss J, Vaughan M: Different forms of Go alpha mRNA arise by alternative splicing of transcripts from a single gene on human chromosome 16. Mol Cell Biol 1991;11:11461155 .

30 Jones DT, Reed RR: Molecular cloning of five GTP-binding protein cDNA species from rat olfactory neuroepithelium. J Biol Chem 1987;262:14241-14249.

31 Strathmann M, Wilkie TM, Simon MI: Alternative splicing produces transcripts encoding two forms of the alpha subunit of GTP-binding protein Go. Proc Natl Acad Sci USA 1990;87:6477-6481.

>32 Hsu WH, Rudolph U, Sanford J, Bertrand P, Olate J, Nelson C, Moss LG, Boyd AE, Codina J, Birnbaumer L: Molecular cloning of a novel splice variant of the alpha subunit of the mammalian Go protein. J Biol Chem 1990;265:11220-11226.

-33 Van Meurs KP, Angus CW, Lavu S, Kung HF, Czarnecki SK, Moss J, Vaughan M: Deduced amino acid sequence of bovine retinal Go alpha: similarities to other guanine nucleotide-binding proteins. Proc Natl Acad Sci USA 1987;84:3107-3111.

34 Damodaran S, Dlugos CA, Wood TD, Rabin RA: Effects of chronic ethanol administration on brain protein levels: a proteomic investigation using 2-D DIGE system. Eur J Pharmacol 2006;547:75-82.

\35 Olate J, Martinez S, Purcell P, Jorquera H, Codina J, Birnbaumer L, Allende J: Molecular cloning and sequence determination of four different cDNA species coding for alpha-subunits of $\mathrm{G}$ proteins from Xenopus laevis oocytes. FEBS Lett 1990;268:27-31.

\$6 Yoon J, Shortridge RD, Bloomquist BT, Schneuwly S, Perdew MH, Pak WL: Molecular characterization of Drosophila gene encoding G0 alpha subunit homolog. J Biol Chem 1989;264:18536-18543.

37 De Sousa SM, Hoveland LL, Yarfitz S, Hurley JB: The Drosophila Go alpha-like G protein gene produces multiple transcripts and is expressed in the nervous system and in ovaries. J Biol Chem 1989;264:18544-18551.

38 Thambi NC, Quan F, Wolfgang WJ, Spiegel A, Forte M: Immunological and molecular characterization of Go alpha-like proteins in the Drosophila central nervous system. J Biol Chem 1989;264:18552-18560. 
-39 Lochrie MA, Mendel JE, Sternberg PW, Simon MI: Homologous and unique $\mathrm{G}$ protein alpha subunits in the nematode Caenorhabditis elegans. Cell Regul 1991;2:135-154.

40 Miura N, Atsumi S, Tabunoki H, Sato R: Expression and localization of three $G$ protein alpha subunits, Go, Gq, and Gs, in adult antennae of the silkmoth (Bombyx mori). J Comp Neurol 2005;485:143-152.

-41 Goldsmith P, Backlund PS Jr, Rossiter K, Carter A, Milligan G, Unson CG, Spiegel A: Purification of heterotrimeric GTP-binding proteins from brain: identification of a novel form of Go. Biochemistry 1988;27:70857090.

42 Lang J: Purification and characterization of subforms of the guanine-nucleotide-binding proteins $\mathrm{G}$ alpha i and $\mathrm{G}$ alpha o. Eur J Biochem 1989;183:687-692.

-43 Scherer NM, Toro MJ, Entman ML, Birnbaumer L: G-protein distribution in canine cardiac sarcoplasmic reticulum and sarcolemma: comparison to rabbit skeletal muscle membranes and to brain and erythrocyte Gproteins. Arch Biochem Biophys 1987;259: 431-440.

44 Strathmann M, Simon MI: G protein diversity: a distinct class of alpha subunits is present in vertebrates and invertebrates. Proc Natl Acad Sci USA 1990;87:9113-9117.

- 45 Tsukamoto T, Toyama R, Itoh H, Kozasa T, Matsuoka M, Kaziro Y: Structure of the human gene and two rat cDNAs encoding the alpha chain of GTP-binding regulatory protein Go: two different mRNAs are generated by alternative splicing. Proc Natl Acad Sci USA 1991;88:2974-2978.

-46 Jiang M, Spicher K, Boulay G, Wang Y, Birnbaumer L: Most central nervous system $\mathrm{D}_{2}$ dopamine receptors are coupled to their effectors by Go. Proc Natl Acad Sci USA 2001; 98:3577-3582.

-47 Linder ME, Pang IH, Duronio RJ, Gordon JI, Sternweis PC, Gilman AG: Lipid modifications of $G$ protein subunits. Myristoylation of Go alpha increases its affinity for beta gamma. J Biol Chem 1991;266:4654-4659.

-48 Mumby SM, Heukeroth RO, Gordon JI, Gilman AG: G-protein alpha-subunit expression, myristoylation, and membrane association in COS cells. Proc Natl Acad Sci USA 1990;87:728-732.

-49 Jones TL, Simonds WF, Merendino JJ Jr, Brann MR, Spiegel AM: Myristoylation of an inhibitory GTP-binding protein alpha subunit is essential for its membrane attachment. Proc Natl Acad Sci USA 1990;87:568572.

50 Gallego C, Gupta SK, Winitz S, Eisfelder BJ, Johnson GL: Myristoylation of the G alpha i2 polypeptide, a $\mathrm{G}$ protein alpha subunit, is required for its signaling and transformation functions. Proc Natl Acad Sci USA 1992;89: 9695-9699.
51 Linder ME, Middleton P, Hepler JR, Taussig R, Gilman AG, Mumby SM: Lipid modifications of $G$ proteins: alpha subunits are palmitoylated. Proc Natl Acad Sci USA 1993;90: 3675-3679.

52 Mumby SM, Kleuss C, Gilman AG: Receptor regulation of G-protein palmitoylation. Proc Natl Acad Sci USA 1994;91:2800-2804.

53 Barclay E, O’Reilly M, Milligan G: Activation of an alpha-2A-adrenoceptor-Galphaol fusion protein dynamically regulates the palmitoylation status of the $\mathrm{G}$ protein but not of the receptor. Biochem J 2005;385:197206.

54 Busconi L, Boutin PM, Denker BM: N-terminal binding domain of Galpha subunits: involvement of amino acids 11-14 of Galphao in membrane attachment. Biochem J 1997;323:239-244.

55 Chen CA, Manning DR: Regulation of G proteins by covalent modification. Oncogene 2001;20:1643-1652.

56 Kobayashi I, Shibasaki H, Takahashi K, Kikkawa S, Ui M, Katada T: Purification of GTPbinding proteins from bovine brain membranes. Identification of heterogeneity of the alpha-subunit of Go proteins. FEBS Lett 1989;257:177-180.

57 McIntire WE, Dingus J, Schey KL, Hildebrandt JD: Characterization of the major bovine brain Go alpha isoforms. Mapping the structural differences between the alpha subunit isoforms identifies a variable region of the protein involved in receptor interactions. J Biol Chem 1998;273:33135-33141.

58 McIntire WE, Schey KL, Knapp DR, Hildebrandt JD: A major $\mathrm{G}$ protein alpha $\mathrm{O}$ isoform in bovine brain is deamidated at Asn346 and Asn347, residues involved in receptor coupling. Biochemistry 1998;37: 14651-14658.

59 Exner T, Jensen ON, Mann M, Kleuss C, Nurnberg B: Posttranslational modification of Galphao1 generates Galphao3, an abundant G protein in brain. Proc Natl Acad Sci USA 1999;96:1327-1332.

60 McIntire WE, Dingus J, Wilcox MD, Hildebrandt JD: The relationship of G(o)alpha subunit deamidation to the tissue distribution, nucleotide binding properties, and betagamma dimer interactions of G(o)alpha subunit isoforms. J Neurochem 1999;73: 633-640

61 Huff RM, Axton JM, Neer EJ: Physical and immunological characterization of a guanine nucleotide-binding protein purified from bovine cerebral cortex. J Biol Chem 1985;260:10864-10871.

62 Vardi N: Alpha subunit of Go localizes in the dendritic tips of ON bipolar cells. J Comp Neurol 1998;395:43-52.

63 Shinohara H, Kato K, Asano T: Differential localization of $\mathrm{G}$ proteins, $\mathrm{Gi}$ and $\mathrm{Go}$, in the olfactory epithelium and the main olfactory bulb of the rat. Acta Anat (Basel) 1992;144 $167-171$
64 Homburger V, Brabet P, Audigier Y, Pantaloni C, Bockaert J, Rouot B: Immunological localization of the GTP-binding protein Go in different tissues of vertebrates and invertebrates. Mol Pharmacol 1987;31:313-319.

65 Liang BT, Hellmich MR, Neer EJ, Galper JB: Development of muscarinic cholinergic inhibition of adenylate cyclase in embryonic chick heart. Its relationship to changes in the inhibitory guanine nucleotide regulatory protein. J Biol Chem 1986;261:9011-9021.

66 Asano T, Kamiya N, Semba R, Kato K: Ontogeny of the GTP-binding protein Go in rat brain and heart. J Neurochem 1988;51:17111716.

67 Milligan G, Tanfin Z, Goureau O, Unson C, Harbon S: Identification of both Gi2 and a novel, immunologically distinct, form of Go in rat myometrial membranes. FEBS Lett 1989;244:411-416.

68 Wolf WP, Spicher K, Haase H, Schulze W: Immunocytochemical localization of the Gprotein subunit, G(o) alpha, in rat heart. Implications for a role of $\mathrm{G}(\mathrm{o})$ alpha in secretion of cardiac hormones. J Mol Cell Cardiol 1998;30:1149-1162.

69 Worley PF, Baraban JM, Van Dop C, Neer EJ, Snyder SH: Go, a guanine nucleotide-binding protein: immunohistochemical localization in rat brain resembles distribution of second messenger systems. Proc Natl Acad Sci USA 1986;83:4561-4565.

70 Gabrion J, Brabet P, Nguyen Than Dao B, Homburger V, Dumuis A, Sebben M, Rouot B, Bockaert J: Ultrastructural localization of the GTP-binding protein Go in neurons. Cell Signal 1989;1:107-123.

71 Galper JB, Klein W, Catterall WA: Muscarinic acetylcholine receptors in developing chick heart. J Biol Chem 1977;252:86928699

72 Luetje CW, Tietje KM, Christian JL, Nathanson NM: Differential tissue expression and developmental regulation of guanine nucleotide binding regulatory proteins and their messenger RNAs in rat heart. J Biol Chem 1988;263:13357-13365.

73 Kawai Y, Arinze IJ: Differential localization and development-dependent expression of G-protein subunits, Go alpha and G beta, in rabbit heart. J Mol Cell Cardiol 1996;28: 1555-1564.

74 Mullaney I, Milligan G: Elevated levels of the guanine nucleotide binding protein, Go, are associated with differentiation of neuroblastoma $\times$ glioma hybrid cells. FEBS Lett 1989; 244:113-118.

-75 Brabet $\mathrm{P}$, Pantaloni C, Rodriguez M, Martinez J, Bockaert J, Homburger V: Neuroblastoma differentiation involves the expression of two isoforms of the alpha-subunit of Go. J Neurochem 1990;54:1310-1320.

76 Brabet P, Pantaloni C, Bockaert J, Homburger V: Metabolism of two Go alpha isoforms in neuronal cells during differentiation. J Biol Chem 1991;266:12825-12828. 
-77 Ben-Shlomo I, Yu Hsu S, Rauch R, Kowalski HW, Hsueh AJ: Signaling receptome: a genomic and evolutionary perspective of plasma membrane receptors involved in signal transduction. Sci STKE 2003;2003:RE9.

78 Florio VA, Sternweis PC: Reconstitution of resolved muscarinic cholinergic receptors with purified GTP-binding proteins. J Biol Chem 1985;260:3477-3483.

-79 Kurose H, Katada T, Haga T, Haga K, Ichiyama A, Ui M: Functional interaction of purified muscarinic receptors with purified inhibitory guanine nucleotide regulatory proteins reconstituted in phospholipid vesicles. J Biol Chem 1986;261:6423-6428.

-80 Ueda H, Harada H, Nozaki M, Katada T, Ui M, Satoh M, Takagi H: Reconstitution of rat brain mu opioid receptors with purified guanine nucleotide-binding regulatory proteins, Gi and Go. Proc Natl Acad Sci USA 1988;85:7013-7017.

81 Lewis DL, Weight FF, Luini A: A guanine nucleotide-binding protein mediates the inhibition of voltage-dependent calcium current by somatostatin in a pituitary cell line. Proc Natl Acad Sci USA 1986;83:90359039.

-82 Law SF, Manning D, Reisine T: Identification of the subunits of GTP-binding proteins coupled to somatostatin receptors. J Biol Chem 1991;266:17885-17897.

83 Hescheler J, Rosenthal W, Trautwein W, Schultz G: The GTP-binding protein, Go, regulates neuronal calcium channels. $\mathrm{Na}$ ture 1987;325:445-447

-84 Ewald DA, Sternweis PC, Miller RJ: Guanine nucleotide-binding protein Go-induced coupling of neuropeptide $\mathrm{Y}$ receptors to $\mathrm{Ca}^{2+}$ channels in sensory neurons. Proc Natl Acad Sci USA 1988;85:3633-3637.

$>85$ Kleuss C, Hescheler J, Ewel C, Rosenthal W, Schultz G, Wittig B: Assignment of G-protein subtypes to specific receptors inducing inhibition of calcium currents. Nature 1991; 353:43-48.

86 Kleuss C, Scherubl H, Hescheler J, Schultz G, Wittig B: Different beta-subunits determine G-protein interaction with transmembrane receptors. Nature 1992;358:424-426.

$>87$ Kleuss C, Scherubl H, Hescheler J, Schultz G, Wittig B: Selectivity in signal transduction determined by gamma subunits of heterotrimeric G proteins. Science 1993;259:832834.

88 Jiang M, Boulay G, Spicher K, Peyton MJ, Brabet P, Birnbaumer L, Rudolph U: Inactivation of the $G$ alpha $i 2$ and $G$ alpha o genes by homologous recombination. Receptors Channels 1997;5:187-192.

89 Jiang M, Gold MS, Boulay G, Spicher K, Peyton M, Brabet P, Srinivasan Y, Rudolph U, Ellison G, Birnbaumer L: Multiple neurological abnormalities in mice deficient in the $G$ protein Go. Proc Natl Acad Sci USA 1998;95: 3269-3274.
-90 Valenzuela D, Han X, Mende U, Fankhauser C, Mashimo H, Huang P, Pfeffer J, Neer EJ, Fishman MC: G alpha(o) is necessary for muscarinic regulation of $\mathrm{Ca}^{2+}$ channels in mouse heart. Proc Natl Acad Sci USA 1997;94:1727-1732.

-91 Dunlap K, Fischbach GD: Neurotransmitters decrease the calcium component of sensory neurone action potentials. Nature 1978;276:837-839.

-92 Dunlap K, Fischbach GD: Neurotransmitters decrease the calcium conductance activated by depolarization of embryonic chick sensory neurones. J Physiol 1981;317: 519-535.

$\$ 93$ Holz GG 4th, Rane SG, Dunlap K: GTPbinding proteins mediate transmitter inhibition of voltage-dependent calcium channels. Nature 1986;319:670-672.

$\checkmark 94$ Scott RH, Dolphin AC: Regulation of calcium currents by a GTP analogue: potentiation of (-)-baclofen-mediated inhibition. Neurosci Lett 1986;69:59-64.

$\$ 95$ Hille B: Modulation of ion-channel function by G-protein-coupled receptors Trends Neurosci 1994;17:531-536.

$\$ 96$ Ewald DA, Pang IH, Sternweis PC, Miller RJ: Differential G protein-mediated coupling of neurotransmitter receptors to $\mathrm{Ca}^{2+}$ channels in rat dorsal root ganglion neurons in vitro. Neuron 1989;2:1185-1193.

$\checkmark 97$ Campbell V, Berrow N, Dolphin AC: GAB$\mathrm{AB}$ receptor modulation of $\mathrm{Ca}^{2+}$ currents in rat sensory neurones by the $\mathrm{G}$ protein $\mathrm{G}(0)$ : antisense oligonucleotide studies. I Physiol 1993;470:1-11.

$\checkmark 98$ Caulfield MP, Jones S, Vallis Y, Buckley NJ, Kim GD, Milligan G, Brown DA: Muscarinic $M$-current inhibition via $G$ alpha $q / 11$ and alpha-adrenoceptor inhibition of $\mathrm{Ca}^{2+}$ current via $G$ alpha o in rat sympathetic neurones. J Physiol 1994;477:415-422.

99 Jan LY, Jan YN: How might the diversity of potassium channels be generated? Trends Neurosci 1990;13:415-419.

100 Pfaffinger PJ, Martin JM, Hunter DD, Nathanson NM, Hille B: GTP-binding proteins couple cardiac muscarinic receptors to a K channel. Nature 1985;317:536-538.

101 Andrade R, Malenka RC, Nicoll RA: A G protein couples serotonin and GABAB receptors to the same channels in hippocampus. Science 1986;234:1261-1265.

102 VanDongen AM, Codina J, Olate J, Mattera R, Joho R, Birnbaumer L, Brown AM: Newly identified brain potassium channels gated by the guanine nucleotide binding protein Go. Science 1988;242:1433-1437.

103 Logothetis DE, Kurachi Y, Galper J, Neer EJ, Clapham DE: The beta gamma subunits of GTP-binding proteins activate the muscarinic $\mathrm{K}^{+}$channel in heart. Nature 1987; 325:321-326
104 Wickman KD, Iniguez-Lluhl JA, Davenport PA, Taussig R, Krapivinsky GB, Linder ME, Gilman AG, Clapham DE: Recombinant G-protein beta gamma-subunits activate the muscarinic-gated atrial potassium channel. Nature 1994;368:255-257.

105 Reuveny E, Slesinger PA, Inglese J, Morales JM, Iniguez-Lluhi JA, Lefkowitz RJ, Bourne HR, Jan YN, Jan LY: Activation of the cloned muscarinic potassium channel by $\mathrm{G}$ protein beta gamma subunits. Nature 1994; 370:143-146.

106 Huang CL, Jan YN, Jan LY: Binding of the $\mathrm{G}$ protein betagamma subunit to multiple regions of $\mathrm{G}$ protein-gated inward-rectifying $\mathrm{K}^{+}$channels. FEBS Lett 1997;405:291298.

107 Lei Q, Jones MB, Talley EM, Schrier AD, McIntire WE, Garrison JC, Bayliss DA: Activation and inhibition of $\mathrm{G}$ protein-coupled inwardly rectifying potassium (Kir3) channels by $\mathrm{G}$ protein beta gamma subunits. Proc Natl Acad Sci USA 2000;97: 9771-9776.

108 Peleg S, Varon D, Ivanina T, Dessauer CW, Dascal N: G-alpha-i controls the gating of the $\mathrm{G}$ protein-activated $\mathrm{K}^{+}$channel, GIRK. Neuron 2002;33:87-99.

109 Cohen-Armon M, Sokolovsky M: Depolarization-induced changes in the muscarinic receptor in rat brain and heart are mediated by pertussis-toxin-sensitive G-proteins. J Biol Chem 1991;266:2595-2605.

110 Cohen-Armon M, Sokolovsky M: Evidence for involvement of the voltage-dependent $\mathrm{Na}^{+}$channel gating in depolarization-induced activation of G-proteins. J Biol Chem 1993;268:9824-9838.

111 Anis Y, Nurnberg B, Visochek L, Reiss N, Naor Z, Cohen-Armon M: Activation of Go-proteins by membrane depolarization traced by in situ photoaffinity labeling of galphao-proteins with $\left[\alpha^{32} \mathrm{P}\right] \mathrm{GTP}$-azidoanilide. J Biol Chem 1999;274:7431-7440.

112 Komwatana P, Dinudom A, Young JA, Cook DI: Cytosolic $\mathrm{Na}^{+}$controls and epithelial $\mathrm{Na}^{+}$channel via the Go guanine nucleotide-binding regulatory protein. Proc Natl Acad Sci USA 1996;93:8107-8111.

$\checkmark 113$ Komwatana P, Dinudom A, Young JA, Cook DI: Activators of epithelial $\mathrm{Na}^{+}$channels inhibit cytosolic feedback control. Evidence for the existence of a $\mathrm{G}$ protein-coupled receptor for cytosolic $\mathrm{Na}^{+}$. J Membr Biol 1998;162:225-232.

114 Katada T, Oinuma M, Ui M: Two guanine nucleotide-binding proteins in rat brain serving as the specific substrate of isletactivating protein, pertussis toxin. Interaction of the alpha-subunits with beta gamma-subunits in development of their biological activities. J Biol Chem 1986;261: 8182-8191.

115 Wong YH, Conklin BR, Bourne HR: Gzmediated hormonal inhibition of cyclic AMP accumulation. Science 1992;255:339342 . 
116 Kobayashi I, Shibasaki H, Takahashi K, Tohyama K, Kurachi Y, Ito H, Ui M, Katada T: Purification and characterization of five different alpha subunits of guanine-nucleotide-binding proteins in bovine brain membranes. Their physiological properties concerning the activities of adenylate cyclase and atrial muscarinic $\mathrm{K}^{+}$channels. Eur J Biochem 1990;191:499-506.

117 Ghil S, Choi JM, Kim SS, Lee YD, Liao Y, Birnbaumer L, Suh-Kim H: Compartmentalization of protein kinase A signaling by the heterotrimeric G protein Go. Proc Natl Acad Sci USA 2006;103:19158-19163.

-118 Mendel JE, Korswagen HC, Liu KS, HajduCronin YM, Simon MI, Plasterk RH, Sternberg PW: Participation of the protein Go in multiple aspects of behavior in C. elegans. Science 1995;267:1652-1655.

-119 Segalat L, Elkes DA, Kaplan JM: Modulation of serotonin-controlled behaviors by Go in Caenorhabditis elegans. Science 1995; 267:1648-1651.

120 Miller KG, Emerson MD, Rand JB: Goalpha and diacylglycerol kinase negatively regulate the Gqalpha pathway in C. elegans. Neuron 1999;24:323-333.

121 Nurrish S, Segalat L, Kaplan JM: Serotonin inhibition of synaptic transmission: Galpha( 0 ) decreases the abundance of UNC-13 at release sites. Neuron 1999;24:231-242.

- 122 Matsuki M, Kunitomo H, Iino Y: Goalpha regulates olfactory adaptation by antagonizing Gqalpha-DAG signaling in Caenorhabditis elegans. Proc Natl Acad Sci USA 2006;103:1112-1117.

123 Mendel J: Go directly (or indirectly) to Gq. Neuron 1999;24:287-288.

124 Kroll SD, Chen J, De Vivo M, Carty DJ, Buku A, Premont RT, Iyengar R: The Q205LGo-alpha subunit expressed in NIH3T3 cells induces transformation. J Biol Chem 1992;267:23183-23188.

125 Kroll SD, Omri G, Landau EM, Iyengar R: Activated alpha subunit of Go protein induces oocyte maturation. Proc Natl Acad Sci USA 1991;88:5182-5186.

126 Baffy G, Yang L, Raj S, Manning DR, Williamson JR: G protein coupling to the thrombin receptor in Chinese hamster lung fibroblasts. J Biol Chem 1994;269:84838487.

127 Van Biesen T, Hawes BE, Raymond JR, Luttrell LM, Koch WJ, Lefkowitz RJ: G(o)-protein alpha-subunits activate mitogen-activated protein kinase via a novel protein kinase C-dependent mechanism. J Biol Chem 1996;271:1266-1269.

128 Jordan JD, Carey KD, Stork PJ, Iyengar R: Modulation of rap activity by direct interaction of Galpha(o) with Rap1 GTPase-activating protein. J Biol Chem 1999;274: 21507-21510.

- 129 Ram PT, Horvath CM, Iyengar R: Stat3mediated transformation of NIH-3T3 cells by the constitutively active Q205L Galphao protein. Science 2000;287:142-144.
130 Jordan JD, He JC, Eungdamrong NJ, Gomes I, Ali W, Nguyen T, Bivona TG, Philips MR, Devi LA, Iyengar R: Cannabinoid receptorinduced neurite outgrowth is mediated by Rap1 activation through G(alpha)o/i-triggered proteasomal degradation of Rap1GAPII. J Biol Chem 2005;280:11413-11421.

$\checkmark 131 \mathrm{He} \mathrm{JC,} \mathrm{Gomes} \mathrm{I,} \mathrm{Nguyen} \mathrm{T,} \mathrm{Jayaram} \mathrm{G,} \mathrm{Ram}$ PT, Devi LA, Iyengar R: The G alpha(o/i)coupled cannabinoid receptor-mediated neurite outgrowth involves Rap regulation of Src and Stat3. J Biol Chem 2005;280: 33426-33434.

132 Antonelli V, Bernasconi F, Wong YH, Vallar L: Activation of B-Raf and regulation of the mitogen-activated protein kinase pathway by the G(o) alpha chain. Mol Biol Cell 2000;11:1129-1142.

133 Bernasconi F, Malgaroli A, Vallar L: Independent regulation of Rap1 and mitogenactivated protein kinase by the alpha chain of Go. Neurosignals 2006;15:180-189.

134 Crespo P, Xu N, Simonds WF, Gutkind JS: Ras-dependent activation of MAP kinase pathway mediated by G-protein beta gamma subunits. Nature 1994;369:418-420.

135 Gutkind JS: The pathways connecting G protein-coupled receptors to the nucleus through divergent mitogen-activated protein kinase cascades. J Biol Chem 1998;273: 1839-1842.

136 Toutant M, Aunis D, Bockaert J, Homburger V, Rouot B: Presence of three pertussis toxin substrates and Go alpha immunoreactivity in both plasma and granule membranes of chromaffin cells. FEBS Lett 1987; 215:339-344

137 Lang J, Nishimoto I, Okamoto T, Regazzi R, Kiraly C, Weller U, Wollheim CB: Direct control of exocytosis by receptor-mediated activation of the heterotrimeric GTPases Gi and $\mathrm{G}(\mathrm{o})$ or by the expression of their active G alpha subunits. EMBO J 1995;14:36353644.

138 Gasman S, Chasserot-Golaz S, Popoff MR, Aunis D, Bader MF: Trimeric G proteins control exocytosis in chromaffin cells. Go regulates the peripheral actin network and catecholamine secretion by a mechanism involving the small GTP-binding protein Rho. J Biol Chem 1997;272:20564-20571.

139 Vitale N, Gensse M, Chasserot-Golaz S, Aunis D, Bader MF: Trimeric G proteins control regulated exocytosis in bovine chromaffin cells: sequential involvement of Go associated with secretory granules and Gi3 bound to the plasma membrane. Eur J Neurosci 1996;8:1275-1285.

140 Gasman S, Chasserot-Golaz S, Hubert P, Aunis D, Bader MF: Identification of a potential effector pathway for the trimeric Go protein associated with secretory granules. Go stimulates a granule-bound phosphatidylinositol 4-kinase by activating RhoA in chromaffin cells. J Biol Chem 1998;273: 16913-16920.
141 Ahnert-Hilger G, Schafer T, Spicher K, Grund C, Schultz G, Wiedenmann B: Detection of G-protein heterotrimers on large dense core and small synaptic vesicles of neuroendocrine and neuronal cells. Eur J Cell Biol 1994;65:26-38.

142 Ahnert-Hilger G, Nurnberg B, Exner T, Schafer T, Jahn R: The heterotrimeric G protein $\mathrm{Go} 2$ regulates catecholamine uptake by secretory vesicles. EMBO J 1998; 17: 406-413.

143 Holtje M, von Jagow B, Pahner I, Lautenschlager M, Hortnagl H, Nurnberg B, Jahn $\mathrm{R}$, Ahnert-Hilger G: The neuronal monoamine transporter VMAT2 is regulated by the trimeric GTPase Go(2). J Neurosci 2000;20:2131-2141.

144 Winter S, Brunk I, Walther DJ, Holtje M, Jiang M, Peter JU, Takamori S, Jahn R, Birnbaumer L, Ahnert-Hilger G: Galphao2 regulates vesicular glutamate transporter activity by changing its chloride dependence. J Neurosci 2005;25:4672-4680.

145 Holtje M, Hofmann F, Lux R, Veh RW, Just I, Ahnert-Hilger G: Glutamate uptake and release by astrocytes is enhanced by Clostridium botulinum $\mathrm{C} 3$ protein. J Biol Chem 2008:283:9289-9299.

146 Strittmatter SM, Valenzuela D, Kennedy TE, Neer EJ, Fishman MC: G0 is a major growth cone protein subject to regulation by GAP-43. Nature 1990;344:836-841.

147 Meiri KF, Pfenninger KH, Willard MB: Growth-associated protein, GAP-43, a polypeptide that is induced when neurons extend axons, is a component of growth cones and corresponds to pp46, a major polypeptide of a subcellular fraction enriched in growth cones. Proc Natl Acad Sci USA 1986;83:3537-3541.

148 Skene JH, Jacobson RD, Snipes GJ, McGuire CB, Norden JJ, Freeman JA: A protein induced during nerve growth (GAP43) is a major component of growth-cone membranes. Science 1986;233:783-786.

149 Benowitz LI, Shashoua VE, Yoon MG: Specific changes in rapidly transported proteins during regeneration of the goldfish optic nerve. J Neurosci 1981;1:300-307.

150 Skene JH, Willard M: Changes in axonally transported proteins during axon regeneration in toad retinal ganglion cells. J Cell Biol 1981;89:86-95.

151 Strittmatter SM, Fishman MC: The neuronal growth cone as a specialized transduction system. Bioessays 1991;13:127-134.

152 Strittmatter SM, Fishman MC, Zhu XP: Activated mutants of the alpha subunit of G(o) promote an increased number of neurites per cell. J Neurosci 1994;14:2327-2338.

153 Xie R, Li L, Goshima Y, Strittmatter SM: An activated mutant of the alpha subunit of $\mathrm{G}(\mathrm{o})$ increases neurite outgrowth via protein kinase C. Brain Res Dev Brain Res 1995;87:77-86. 
154 Kindt KS, Tam T, Whiteman S, Schafer WR: Serotonin promotes G(o)-dependent neuronal migration in Caenorhabditis elegans. Curr Biol 2002;12:1738-1747.

-155 Horgan AM, Copenhaver PF: G proteinmediated inhibition of neuronal migration requires calcium influx. J Neurosci 1998; 18:4189-4200.

156 Zheng JQ, Poo MM: Calcium signaling in neuronal motility. Annu Rev Cell Dev Biol 2007;23:375-404.

-157 Guillen A, Semeriva M, Bockaert J, Homburger V: The transduction signalling protein Go during embryonic development of Drosophila melanogaster. Cell Signal 1991; 3:341-352.

-158 Wolfgang WJ, Quan F, Thambi N, Forte M: Restricted spatial and temporal expression of G-protein alpha subunits during Drosophila embryogenesis. Development 1991; 113:527-538.

-159 Guillen A, Jallon JM, Fehrentz JA, Pantaloni C, Bockaert J, Homburger V: A Go-like protein in Drosophila melanogaster and its expression in memory mutants. Embo J 1990;9:1449-1455.

160 Ferris J, Ge H, Liu L, Roman G: G(o) signaling is required for Drosophila associative learning. Nat Neurosci 2006;9:1036-1040.

- 161 Katanaev VL, Ponzielli R, Semeriva M, Tomlinson A: Trimeric G protein-dependent frizzled signaling in Drosophila. Cell 2005;120:111-122.

$\checkmark 162$ Katanaev VL, Tomlinson A: Dual roles for the trimeric $G$ protein Go in asymmetric cell division in Drosophila. Proc Natl Acad Sci USA 2006;103:6524-6529.

$\checkmark 163$ Brouillet E, Trembleau A, Galanaud D, Volovitch M, Bouillot C, Valenza C, Prochiantz A, Allinquant B: The amyloid precursor protein interacts with Go heterotrimeric protein within a cell compartment specialized in signal transduction. J Neurosci 1999;19:1717-1727.

-164 Nishimoto I, Okamoto T, Matsuura Y, Takahashi S, Okamoto T, Murayama Y, Ogata E: Alzheimer amyloid protein precursor complexes with brain GTP-binding protein G(o). Nature 1993;362:75-79.

165 Okamoto T, Takeda S, Giambarella U, Murayama Y, Matsui T, Katada T, Matsuura Y, Nishimoto I: Intrinsic signaling function of APP as a novel target of three V642 mutations linked to familial Alzheimer's disease. Embo J 1996;15:3769-3777.
166 Yamatsuji T, Okamoto T, Takeda S, Murayama Y, Tanaka N, Nishimoto I: Expression of V642 APP mutant causes cellular apoptosis as Alzheimer trait-linked phenotype. Embo J 1996;15:498-509.

167 Zhao B, Chrest FJ, Horton WE Jr, Sisodia SS, Kusiak JW: Expression of mutant amyloid precursor proteins induces apoptosis in PC12 cells. J Neurosci Res 1997;47:253263.

168 Giambarella U, Yamatsuji T, Okamoto T, Matsui T, Ikezu T, Murayama Y, Levine MA, Katz A, Gautam N, Nishimoto I: G protein betagamma complex-mediated apoptosis by familial Alzheimer's disease mutant of APP. EMBO J 1997;16:48974907.

169 McPhie DL, Coopersmith R, Hines-Peralta A, Chen Y, Ivins KJ, Manly SP, Kozlowski MR, Neve KA, Neve RL: DNA synthesis and neuronal apoptosis caused by familial Alzheimer disease mutants of the amyloid precursor protein are mediated by the $\mathrm{p} 21$ activated kinase PAK3. J Neurosci 2003;23. 6914-6927.

170 Smine A, Xu X, Nishiyama K, Katada T, Gambetti P, Yadav SP, Wu X, Shi YC, Yasuhara S, Homburger V, Okamoto T: Regulation of brain G-protein go by Alzheimer's disease gene presenilin-1. J Biol Chem 1998; 273:16281-16288.

171 Wolozin B, Iwasaki K, Vito P, Ganjei JK, Lacana E, Sunderland T, Zhao B, Kusiak JW, Wasco W, D'Adamio L: Participation of presenilin 2 in apoptosis: enhanced basal activity conferred by an Alzheimer mutation. Science 1996;274:1710-1713.

172 Roth KA: Caspases, apoptosis, and Alzheimer disease: causation, correlation, and confusion. J Neuropathol Exp Neurol 2001; 60:829-838.

173 Bozzi Y, Borrelli E: Dopamine in neurotoxicity and neuroprotection: what do $\mathrm{D}_{2}$ receptors have to do with it? Trends Neurosci 2006;29:167-174.

174 Okada F, Crow TJ, Roberts GW: G-proteins (Gi, Go) in the basal ganglia of control and schizophrenic brain. J Neural Transm Gen Sect 1990;79:227-234.

175 Okada F, Crow TJ, Roberts GW: G proteins (Gi, Go) in the medial temporal lobe in schizophrenia: preliminary report of a neurochemical correlate of structural change. J Neural Transm Gen Sect 1991;84:147-153.
176 Okada F, Tokumitsu Y, Takahashi N, Crow TJ, Roberts GW: Reduced concentrations of the alpha-subunit of GTP-binding protein Go in schizophrenic brain. J Neural Transm Gen Sect 1994;95:95-104.

177 Yang CQ, Kitamura N, Nishino N, Shirakawa $\mathrm{O}$, Nakai $\mathrm{H}$ : Isotype-specific $\mathrm{G}$ protein abnormalities in the left superior temporal cortex and limbic structures of patients with chronic schizophrenia. Biol Psychiatry 1998;43:12-19.

178 Tani M, Mui K, Minami Y, Kiriike N: Association of a GTP-binding protein Go alpha subunit mutation with schizophrenia. Mol Psychiatry 2001;6:359.

179 Schiller PH: The ON and OFF channels of the visual system. Trends Neurosci 1992;15: 86-92.

180 Nakajima Y, Iwakabe H, Akazawa C, Nawa H, Shigemoto R, Mizuno N, Nakanishi S: Molecular characterization of a novel retinal metabotropic glutamate receptor mGluR6 with a high agonist selectivity for L-2-amino-4-phosphonobutyrate. J Biol Chem 1993;268:11868-11873.

181 Masu M, Iwakabe H, Tagawa Y, Miyoshi T, Yamashita M, Fukuda Y, Sasaki H, Hiroi K, Nakamura Y, Shigemoto R, et al: Specific deficit of the ON response in visual transmission by targeted disruption of the mGluR6 gene. Cell 1995;80:757-765.

182 Dhingra A, Lyubarsky A, Jiang M, Pugh EN Jr, Birnbaumer L, Sterling P, Vardi N: The light response of $\mathrm{ON}$ bipolar neurons requires G(alpha)o. J Neurosci 2000;20:90539058.

183 Dhingra A, Jiang M, Wang TL, Lyubarsky A, Savchenko A, Bar-Yehuda T, Sterling P, Birnbaumer L, Vardi N: Light response of retinal $\mathrm{ON}$ bipolar cells requires a specific splice variant of Galpha(o). J Neurosci 2002; 22:4878-4884.

184 Duan SZ, Christe M, Milstone DS, Mortensen RM: Go but not Gi2 or Gi3 is required for muscarinic regulation of heart rate and heart rate variability in mice. Biochem Biophys Res Commun 2007;357:139143.

185 Zhu M, Gach AA, Liu G, Xu X, Lim CC, Zhang JX, Mao L, Chuprun K, Koch WJ, Liao R, Koren G, Blaxall BC, Mende U: Enhanced calcium cycling and contractile function in transgenic hearts expressing constitutively active G(alpha)o* protein. Am J Physiol 2008;294:H1335-H1347. 